Keywords: Small Column Ion

Exchange, SCIX, MST, CST,

DWPF, Glass

Retention: Permanent

\title{
Paper Study Evaluations of the Introduction of Small Column Ion Exchange (SCIX) Waste Streams to the Defense Waste Processing Facility
}

\author{
K. M. Fox \\ T. B. Edwards \\ M. E. Stone \\ D. C. Koopman
}

June 2010

Savannah River National Laboratory Savannah River Nuclear Solutions, LLC Aiken, SC 29808

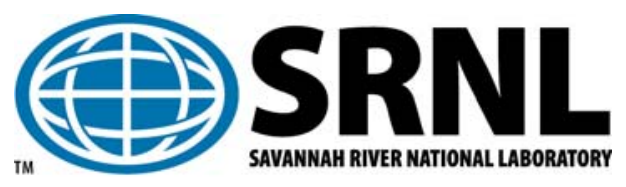




\section{DISCLAIMER}

This work was prepared under an agreement with and funded by the U.S. Government. Neither the U.S. Government or its employees, nor any of its contractors, subcontractors or their employees, makes any express or implied:

1. warranty or assumes any legal liability for the accuracy, completeness, or for the use or results of such use of any information, product, or process disclosed; or

2. representation that such use or results of such use would not infringe privately owned rights; or

3. endorsement or recommendation of any specifically identified commercial product, process, or service.

Any views and opinions of authors expressed in this work do not necessarily state or reflect those of the United States Government, or its contractors, or subcontractors.

\section{Printed in the United States of America \\ Prepared for U.S. Department of Energy}




\section{REVIEWS AND APPROVALS}

AUTHORS:

K. M. Fox, Process Technology Programs Date

T. B. Edwards, Applied Computational Engineering and Statistics Date

M. E. Stone, Process Technology Programs

Date

D. C. Koopman, Process Technology Programs

Date

TECHNICAL REVIEW:

D. K. Peeler, Process Technology Programs

Date

APPROVAL:

C. C. Herman, Manager

Date

Process Technology Programs

S. L. Marra, Manager

Date

Environmental \& Chemical Process Technology Research Programs

J. E. Occhipinti, Manager

Date

Waste Solidification Engineering

T. H. Huff, Design Authority Manager

Date

Small Column Ion Exchange Program 


\section{EXECUTIVE SUMMARY}

The objective of this paper study is to provide guidance on the impact of Monosodium Titanate (MST) and Crystalline Silicotitanate (CST) streams from the Small Column Ion Exchange (SCIX) process on the Defense Waste Processing Facility (DWPF) flowsheet and glass waste form. A series of waste processing scenarios was evaluated, including projected compositions of Sludge Batches 8 through 17 (SB8 through SB17), MST additions, CST additions to Tank 40 or to a sludge batch preparation tank (Tank 42 or Tank 51, referred to generically as Tank 51 in this report), streams from the Salt Waste Processing Facility (SWPF), and two canister production rates. A wide array of potential glass frit compositions was used to support this assessment. The sludge and frit combinations were evaluated using the predictive models in the current DWPF Product Composition Control System (PCCS). The results were evaluated based on the number of frit compositions available for a particular sludge composition scenario. A large number of candidate frit compositions (e.g., several dozen to several hundred) is typically a good indicator of a sludge composition for which there is flexibility in forming an acceptable waste glass and meeting canister production rate commitments. The MST and CST streams will significantly increase the concentrations of certain components in glass, such as $\mathrm{Nb}_{2} \mathrm{O}_{5}, \mathrm{TiO}_{2}$, and $\mathrm{ZrO}_{2}$, to levels much higher than have been previously processed at DWPF. Therefore, several important assumptions, described in detail in the report, had to be made in performing the evaluations.

The results of the paper studies, which must be applied carefully given the assumptions made concerning the impact of higher $\mathrm{Ti}, \mathrm{Zr}$, and $\mathrm{Nb}$ concentrations on model validity, provided several observations:

- There was difficulty in identifying a reasonable number of candidate frits (and in some cases an inability to identify any candidate frits) when a waste loading of $40 \%$ is targeted for Sludge Batches 8, 16, and 17, regardless of the addition of SCIX or SWPF streams. This indicates that the blending strategy for these sludge batches should be reevaluated by Savannah River Remediation (SRR).

- In general, candidate frits were available to accommodate CST additions to either Tank 40 or Tank 51. A larger number of candidate frits were typically available for the sludge batches when CST is added to Tank 51 rather than Tank 40, meaning that more compositional flexibility would be available for frit selection and DWPF operation. Note however that for SB8 and SB17, no candidate frits were available to accommodate CST going to Tank 40 with and without SWPF streams. The addition of SWPF streams generally improves the number of candidate frits available for processing of a given sludge batch.

- The change in production rate from 40 Sludge Receipt and Adjustment Tank (SRAT) batches per year (i.e., the current production rate) to 75 SRAT batches per year, without SWPF streams included, had varied results in terms of the number of candidate frits available for processing of a given sludge batch. Therefore, this variable is not of much concern in terms of incorporating the SCIX streams. Note that the evaluation at 75 SRAT batches per year (approximately equivalent to 325 canisters per year) is more conservative in terms of the impact of SCIX streams as compared to a production rate of 400 canisters per year.

Overall, the outcome of this paper study shows no major issues with the ability to identify an acceptable glass processing window when CST from the SCIX process is transferred to either Tank 40 or Tank 51. The assumptions used and the model limitations identified in this report must be addressed through further experimental studies, which are currently being performed. As changes occur to the planned additions of MST and CST, or to the sludge batch preparation 
strategy, additional evaluations will be performed to determine the potential impacts. As stated above, the issues with Sludge Batches 8, 16, and 17 should be further evaluated by SRR.

A review of Chemical Process Cell (CPC) processing identified no changes to the recommendations from the previous review of the SCIX process impacts. Recommendations for testing were made during the previous review to evaluate the impact of CST on the rheological properties of DWPF process streams and evaluate the impact of CST on catalytic hydrogen generation during CPC processing. 


\section{TABLE OF CONTENTS}

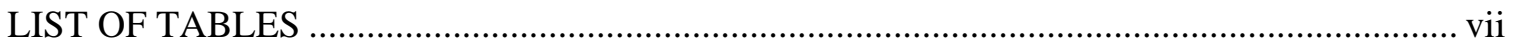

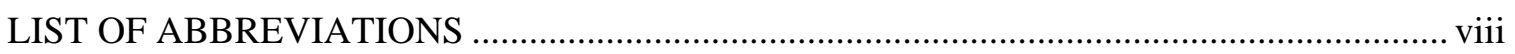

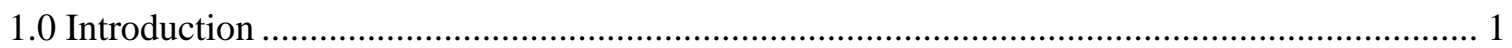

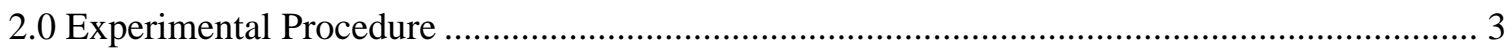

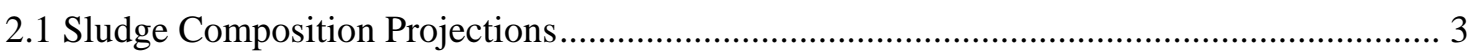

2.2 Glass Composition Paper Study Assessments ..................................................................... 4

2.3 Assumptions Used in PCCS Model Predictions ................................................................ 4

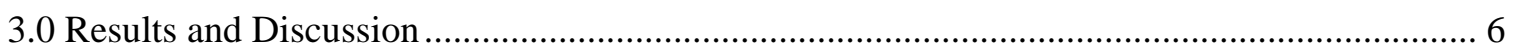

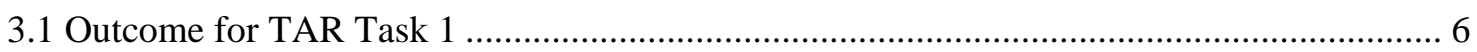

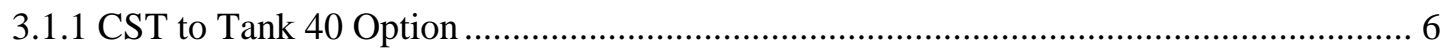

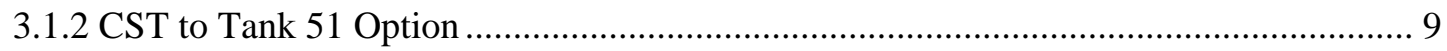

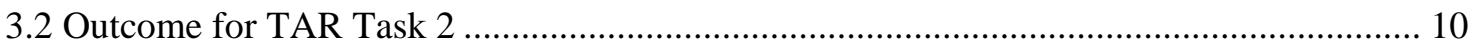

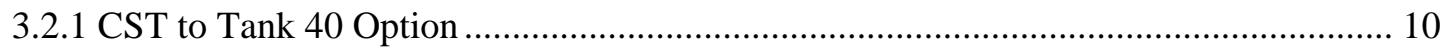

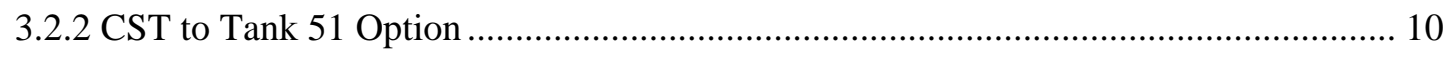

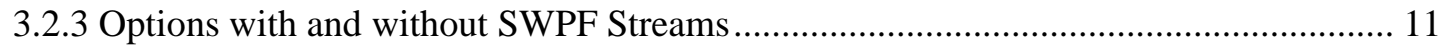

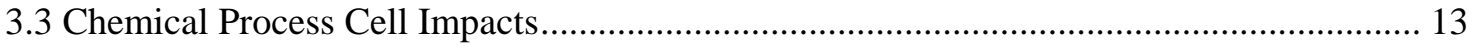

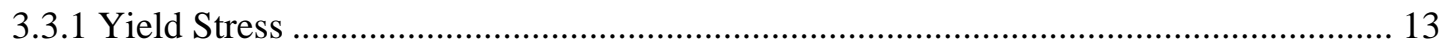

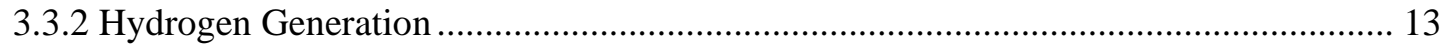

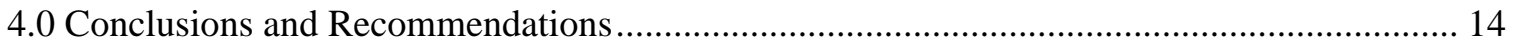

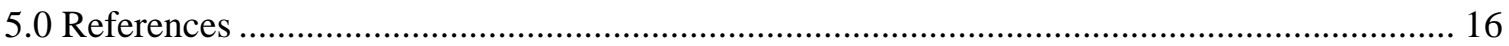

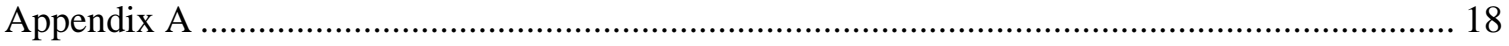




\section{LIST OF TABLES}

Table 3-1. Concentration Ranges for Components of the Frit Composition Array.

Table 3-2. MAR Assessment Results for CST Additions to Tank 40 at 40 SRAT Batches Annually.

Table 3-3. MAR Assessment Results for SB8 with CST Additions to Tank 40 at 40 SRAT Batches Annually.

Table 3-4. Concentration Ranges for Components of a Larger Frit Composition Array Used with SB8.

Table 3-5. MAR Assessment Results for SB8 with CST Additions to Tank 40 at 40 SRAT Batches Annually Using a Larger Frit Array.

Table 3-6. MAR Assessment Results for Sludge-Only Versions of SB8, SB16, and SB17......... 9

Table 3-7. MAR Assessment Results for CST Additions to Tank 51 at 40 SRAT Batches Annually

Table 3-8. MAR Assessment Results for CST Additions to Tank 40 with SWPF Streams at 75 SRAT Batches Annually.

Table 3-9. MAR Assessment Results for CST Additions to Tank 51 with SWPF Streams at 75 SRAT Batches Annually.

Table 3-10. MAR Assessment Results for CST Additions to Tank 40 with and without SWPF Streams at 75 SRAT Batches Annually.

Table 3-11. MAR Assessment Results for CST Additions to Tank 51 with and without SWPF Streams at 75 SRAT Batches Annually. 


\section{LIST OF ABBREVIATIONS}

$\begin{array}{ll}\text { ARP/MCU } & \text { Actinide Removal Process / Modular Caustic Side Solvent Extraction } \\ \text { CPC } & \text { Unit } \\ \text { CST } & \text { Chemical Process Cell } \\ \Delta \mathrm{G}_{\mathrm{i}} & \text { Crystalline Silicotitanate } \\ \text { DWPF } & \text { Free energy of hydration } \\ \text { HLW } & \text { Defense Waste Processing Facility } \\ \text { MAR } & \text { High Level Waste } \\ \text { MST } & \text { Measurement Acceptability Region } \\ \text { PAR } & \text { Monosodium Titanate } \\ \text { PCCS } & \text { Property Acceptability Region } \\ \text { RMF } & \text { Product Composition Control System } \\ \text { SB8, SB9, etc. } & \text { Rotary Micro Filtration } \\ \text { SCIX } & \text { Sludge Batch 8, Sludge Batch 9, etc. } \\ \text { SME } & \text { Small Column Ion Exchange } \\ \text { SRAT } & \text { Slurry Mix Evaporator } \\ \text { SRNL } & \text { Sludge Receipt and Adjustment Tank } \\ \text { SRR } & \text { Savannah River National Laboratory } \\ \text { SWPF } & \text { Savannah River Remediation } \\ \text { TAR } & \text { Salt Waste Processing Facility } \\ \text { WL } & \text { Technical Assistance Request } \\ & \text { Waste Loading }\end{array}$




\subsection{Introduction}

The Savannah River Site Tank Farm will begin a process referred to as Small Column Ion Exchange (SCIX) to disposition salt solution in fiscal year 2014. In the first step of the process, salt solution retrieved from various waste tanks will be struck with Monosodium Titanate (MST) to remove key actinides. The salt solution will then be processed using Rotary Micro Filtration (RMF) to remove the MST and any insoluble solids. The MST and insoluble solids will accumulate on the bottom of Tank 41. The filtrate from RMF will be fed to the SCIX apparatus, also in Tank 41, to remove the ${ }^{137} \mathrm{Cs}$ using Crystalline Silicotitanate (CST) resin. The decontaminated salt solution from SCIX will be sent to the Saltstone Facility for immobilization in grout. The ${ }^{137}$ Cs-laden CST resin will be sluiced and ground for particle size reduction, then sent to the Defense Waste Processing Facility (DWPF) for immobilization in glass. These processes mirror the current disposition paths for streams associated with the Salt Waste Processing Facility (SWPF), which is under construction.

The MST and insoluble solids from Tank 41 will periodically be transferred to a sludge batch preparation tank (Tank 42 or Tank 51, referred to generically as Tank 51 in this report) as part of the High Level Waste (HLW) sludge batch preparation process for DWPF. The ground, ${ }^{137} \mathrm{Cs}-$ laden CST material (hereafter referred to simply as CST) from SCIX may be transferred to either Tank 40 or Tank 51 prior to being processed at DWPF. The path of this material depends on the results of evaluations currently being performed by the SCIX team. If ground CST can be dropped into Tank 41 (depending on heat loading issues), the CST would later be sent to Tank 51 using an existing underground transfer line. If ground CST cannot be dropped into Tank 41, periodic transfers of CST to Tank 40 would be the preferred route due to the physical locations of the tanks and the piping and shielding required for the transfers. However, since Tank 40 serves as the feed tank for DWPF, periodic additions of CST to Tank 40 would mean that the composition of an individual sludge batch would change over time as it is processed by DWPF.

The objective of this paper study is to provide guidance on the impact of MST and CST streams from the SCIX process on the DWPF Chemical Process Cell (CPC) flowsheet and the projected operating windows defined by the DWPF process control models. A series of waste processing scenarios was evaluated, including projected compositions of Sludge Batches 8 through 17 (SB8 through SB17), MST additions, CST additions to Tank 40 or Tank 51, streams from the SWPF, and two production rates. A wide array of potential glass frit compositions was included. The sludge and frit combinations were evaluated using the predictive models in the current DWPF Product Composition Control System (PCCS). The results were evaluated based on the number of frit compositions available that can provide a useful projected operating window for a particular sludge composition scenario. A large number of candidate frit compositions (e.g., several dozen to several hundred) is typically a good indicator of a sludge composition for which there is flexibility in forming an acceptable waste glass and meeting canister production rate commitments. The MST and CST streams will significantly increase the concentrations of certain components in glass, such as $\mathrm{Nb}_{2} \mathrm{O}_{5}, \mathrm{TiO}_{2}$, and $\mathrm{ZrO}_{2}$, to levels much higher than have been previously processed at DWPF. ${ }^{a}$ Challenges to the current PCCS model applicability regions and DWPF processing constraints are discussed, and suggestions for further experimental studies are provided.

\footnotetext{
${ }^{a}$ Note that the concentration of cesium included with the CST stream was assumed to be below reportable levels for the DWPF PCCS. A maximum of $1.19 \mathrm{wt} \%$ Cs in the spent CST stream to DWPF has been projected. ${ }^{1}$ Cesium from the SWPF streams was not considered. Other concerns related to increased cesium concentrations (e.g., shielding, etc.) are beyond the scope of this report, but should be considered before any process decisions are made.
} 
A similar study by Peeler and Edwards in 2007 determined that the periodic addition of CST to Tank 40 was not a viable option in terms of producing acceptable glass compositions. ${ }^{2}$ Blending of CST in Tank 51 appeared to be viable, as well as direct transfer of CST to DWPF. The study also identified the need to expand the current PCCS models to incorporate higher concentrations of $\mathrm{Nb}_{2} \mathrm{O}_{5}, \mathrm{TiO}_{2}$, and $\mathrm{ZrO}_{2}$. In addition, a previous study evaluated the impacts of the CST to the pretreatment processing in the CPC. ${ }^{3}$ The impacts of CST on the CPC process were expected to be minor, but some experimental testing was proposed for verification. The work described here builds on the previous studies by evaluating updated sludge composition projections and MST/CST addition strategies.

This study was initiated by a Savannah River Remediation (SRR) Technical Assistance Request (TAR). ${ }^{4}$ 


\subsection{Experimental Procedure}

\subsection{Sludge Composition Projections}

The TAR initiating this study was divided into three tasks. The first two tasks are addressed in this report. ${ }^{\mathrm{a}}$ Task 1 requested an assessment of the impacts of the SCIX process streams added to either Tank 40 or Tank 51 using updated estimates of the $\mathrm{MST}^{5}$ and $\mathrm{CST}^{1}$ compositions, quantities, and processing rates. Task 1 also requested that the sludge batch composition projections $^{6}$ and canister production rates assumed for the previous evaluation ${ }^{2}$ be used again. Streams from SWPF were not included in Task 1.

Based on these inputs, the Savannah River National Laboratory (SRNL) developed a series of sludge composition projections, which are detailed in Appendix A, to support the Task 1 evaluation. It was assumed that MST will be added during the preparation of each sludge batch (e.g., to Tank 51). Table A-1 lists the composition projections for CST added to Tank 40 with a processing rate of 40 DWPF Sludge Receipt and Adjustment Tank (SRAT) batches per year (equivalent to approximately 200 canisters per year). ${ }^{b}$ Three projections for each sludge batch are listed since the addition of CST to Tank 40 changes the composition of the sludge batches as they are processed. The three projections represent the composition at the beginning, middle, and end of each sludge batch, and the corresponding SRAT batch numbers are given. Table A-2 lists the composition projections of the sludge batches (as calcined oxides) with CST added to Tank 51 at a processing rate of 40 SRAT batches per year. In this case only one composition projection is provided for each sludge batch since the addition of CST to Tank 51 means that the sludge batch composition will remain constant throughout processing at DWPF.

Task 2 of the TAR requested an assessment of the impacts of the SCIX process streams added to either Tank 40 or Tank 51 again using updated estimates of the $\mathrm{MST}^{5}$ and $\mathrm{CST}^{1}$ compositions, quantities, and processing rates. Task 2 also requested that updated sludge composition projections be used, along with an increased production rate of 75 SRAT batches per year at $40 \%$ waste loading (equivalent to approximately 325 canisters per year), ${ }^{\mathrm{c}}$ and additions of streams from SWPF. ${ }^{7}$ SRR provided the sludge batch composition projections used for the Task 2 evaluation. ${ }^{\mathrm{d}}$ It was assumed that the SWPF additions bound any additions from the Actinide Removal Process and Modular Caustic Side Solvent Extraction Unit (ARP/MCU) prior to the startup of SWPF.

Based on these inputs, SRNL developed a series of sludge composition projections to support the Task 2 evaluation, which are detailed in Appendix A. It was assumed that MST will be added on a batch preparation basis. Table A-3 lists the composition projections for CST added to Tank 40 with SWPF streams included and a production rate of 75 SRAT batches per year. Three

\footnotetext{
a The third task will be addressed at a later date as it requires selection of an Alternate Reductant flowsheet for implementation at DWPF.

$\mathrm{b}$ The 40 SRAT batches per year production rate was developed based on a target of 200 canisters per year, each containing 4000 pounds of glass at $36 \%$ waste loading, with a sludge batch solids content of $20 \%$ and calcine factor of 0.65 , a sludge slurry density of $1.11 \mathrm{~g} / \mathrm{cm}^{3}$, and a SRAT cycle volume of 6000 gallons. The values were not adjusted for the additions of the SCIX streams.

${ }^{\mathrm{c}}$ The 75 SRAT batches per year production rate was developed using an approximate ratio of SRAT batches to canisters produced at the 40 SRAT batches per year production rate and an adjustment to $40 \%$ waste loading. The values were not adjusted for the additions of the SCIX streams.

${ }^{\mathrm{d}}$ Composition projections for SB8 through SB17 used for the TAR Task 2 evaluation were provided via email by D. D. Larsen on April 15, 2010. The projections, provided as calcined oxides, are based on "Liquid Waste System Plan," SRR-LWP-2009-00001, Revision 15, January 11, 2010. Note that these projections did not include sulfate concentrations.
} 
projections for each sludge batch and their corresponding SRAT batch numbers are again listed, representing the composition at the beginning, middle, and end of each sludge batch. Table A-4 lists the composition projections for CST added to Tank 51 with SWPF streams included and a production rate of 75 SRAT batches per year. Table A- 5 and Table A-6 list similar compositions for CST additions to Tank 40 and Tank 51 respectively, but without the SWPF streams included. These projections were included so that the impact of intermittent inclusion of the SWPF streams could be evaluated.

\subsection{Glass Composition Paper Study Assessments}

Paper studies were completed using the Nominal and Variation Stage assessment process developed by Peeler and Edwards. ${ }^{8}$ Nominal Stage assessments were performed by combining each of the nominal sludge composition projections in Appendix A with an array of candidate frit compositions over a series of waste loadings from 30 to 55\%, and evaluating the resulting glass compositions against the PCCS Measurement Acceptability Region (MAR). The results of the Nominal Stage assessments provided projected operating windows - or waste loading intervals where the predicted processing and product performance properties of the glass were acceptable for each frit and sludge combination. The results were reviewed to identify candidate frit compositions that provided projected operating windows spanning at least $35-45 \%$ waste loading (WL), assuming a target waste loading of $40 \%$ at DWPF. The number of frits available that provided these projected operating windows and the ranges of component concentrations among those frits were used as a measure of the flexibility in producing a PCCS-acceptable glass waste form for a given sludge composition projection.

\subsection{Assumptions Used in PCCS Model Predictions}

The major property models included in PCCS predict liquidus temperature, ${ }^{9}$ viscosity, ${ }^{10}$ nepheline formation, ${ }^{11}$ and chemical durability ${ }^{\mathrm{a}}$ of the waste glass product. The sludge compositions evaluated in this study present challenges to these models as a result of their increased concentrations of $\mathrm{Nb}_{2} \mathrm{O}_{5}, \mathrm{TiO}_{2}$, and $\mathrm{ZrO}_{2}$. More specifically:

- A 2 wt \% $\mathrm{TiO}_{2}$ Property Acceptability Region (PAR) limit is currently incorporated in PCCS. ${ }^{14}$ This limit was ignored for the purposes of this study since the $\mathrm{TiO}_{2}$ concentrations in some of the sludge composition projections evaluated here result in $\mathrm{TiO}_{2}$ concentrations in glass that are considerably higher than $2 \mathrm{wt} \%$. However, it may not be appropriate to ignore this limit given that the impacts of higher $\mathrm{TiO}_{2}$ concentrations on liquidus temperature and viscosity for DWPF glasses have not yet been determined. Thus, additional testing is being performed to assess the impacts of these higher concentrations, and, for the purposes of this report, the impacts were ignored.

- The impacts of higher $\mathrm{ZrO}_{2}$ concentrations on liquidus temperature and viscosity for DWPF glasses are not yet known.

- DWPF does not measure $\mathrm{Nb}_{2} \mathrm{O}_{5}$ concentrations during Slurry Mix Evaporator (SME) acceptability assessments since it has not been present at concentrations greater than 0.5 wt \% in past processing of high level waste. The updated free energy of hydration $\left(\Delta \mathrm{G}_{\mathrm{i}}\right)$ term for $\mathrm{Nb}_{2} \mathrm{O}_{5}{ }^{15}$ was not used in this study since it has not yet been incorporated into PCCS. Since the revised term for $\mathrm{Nb}_{2} \mathrm{O}_{5}$ is more positive than the previous term ${ }^{16}$ and indicates better durability ( $+33.18 \mathrm{kcal} /$ mole compared to $+2.93 \mathrm{kcal} / \mathrm{mole})$, not taking credit for the impact of $\mathrm{Nb}_{2} \mathrm{O}_{5}$ on durability as done in this study can be considered conservative. The impacts of higher $\mathrm{Nb}_{2} \mathrm{O}_{5}$ concentrations on liquidus temperature and viscosity for DWPF glasses are not yet known.

\footnotetext{
${ }^{a}$ Chemical durability is defined by the Product Consistency Test ${ }^{12}$ and is predicted in terms of the preliminary glass dissolution estimator, $\Delta \mathrm{G}_{\mathrm{p}}{ }^{13}$
} 
An experimental program is underway to identify any issues with the predictive models associated with increased concentrations of $\mathrm{Nb}_{2} \mathrm{O}_{5}, \mathrm{TiO}_{2}$, and $\mathrm{ZrO}_{2}{ }^{17}{ }^{18}$ Without the completion of these experiments, the potential issues identified above suggest that the results presented in this report and their utility must be considered carefully since they were developed using the current PCCS models, which may not be entirely applicable to, or validated for, the compositional regions of interest. 


\subsection{Results and Discussion}

\section{1 $\underline{\text { Outcome for TAR Task } 1}$}

\subsubsection{CST to Tank 40 Option}

An array of glass frit compositions was developed to support the paper study assessments. The four components typically used in DWPF frits $-\mathrm{B}_{2} \mathrm{O}_{3}, \mathrm{Li}_{2} \mathrm{O}, \mathrm{Na}_{2} \mathrm{O}$, and $\mathrm{SiO}_{2}$ - were included. Concentration ranges for each of these components are listed in Table 3-1. The concentration of each component was varied in $1 \mathrm{wt} \%$ increments, resulting in a total of 1,144 potential frit compositions in the array.

Table 3-1. Concentration Ranges for Components of the Frit Composition Array.

\begin{tabular}{|c|c|}
\hline Frit Oxide & $\begin{array}{c}\text { Concentration Range } \\
\text { (wt \%) }\end{array}$ \\
\hline $\mathrm{B}_{2} \mathrm{O}_{3}$ & $8-20$ \\
\hline $\mathrm{Li}_{2} \mathrm{O}$ & $5-12$ \\
\hline $\mathrm{Na}_{2} \mathrm{O}$ & $0-10$ \\
\hline $\mathrm{SiO}_{2}$ & $58-87$ \\
\hline
\end{tabular}

CST additions to Tank 40 at a processing rate of 40 SRAT batches per year were evaluated first. The results of Nominal Stage MAR assessments using the 1,144 frits outlined in Table 3-1 and the sludge compositions given in Appendix A, Table A-1, are given in Table 3-2. The number of frits available that provide projected operating windows of at least $35-45 \%$ WL is listed for each sludge batch. Note that this number only includes frit compositions that gave projected operating windows of at least 35-45\% WL for all three of the SRAT batches (beginning, middle, and end of processing) evaluated for each sludge batch, as it was assumed that a frit change during processing of an individual sludge batch would be undesirable. A larger number of available frit compositions for a given sludge composition projection (and therefore wider concentration ranges for the frit components) indicates that flexibility is available to tailor the frit in response to other issues - such as improved melt rate or sulfur retention - while producing a PCCS-acceptable glass. 
Table 3-2. MAR Assessment Results for CST Additions to Tank 40 at 40 SRAT Batches Annually.

\begin{tabular}{|c|c|c|c|c||}
\hline $\begin{array}{c}\text { Sludge } \\
\text { Batch }\end{array}$ & $\begin{array}{c}\text { Number of frits providing } \\
\text { projected operating windows of } \\
\text { at least 35-45\% WL }{ }^{\dagger}\end{array}$ & $\begin{array}{c}\text { Frit } \mathbf{B}_{2} \mathbf{O}_{3} \\
\text { Range } \\
\text { (wt \%) }\end{array}$ & $\begin{array}{c}\text { Frit } \mathbf{L i}_{2} \mathbf{O} \\
\text { Range } \\
\text { (wt \%) }\end{array}$ & $\begin{array}{c}\text { Frit } \mathbf{~ N a}_{2} \mathbf{O} \\
\text { Range } \\
\text { (wt \%) }\end{array}$ \\
\hline SB8 & 1 & 8 & 5 & 9 \\
\hline SB9 & 70 & $8-16$ & $5-9$ & $0-8$ \\
\hline SB10 & 61 & $8-16$ & $5-9$ & $0-7$ \\
\hline SB11 & 44 & $8-13$ & $5-10$ & $0-8$ \\
\hline SB12 & 264 & $8-20$ & $5-12$ & $0-10$ \\
\hline SB13 & 298 & $8-20$ & $5-12$ & $0-10$ \\
\hline SB14 & 166 & $8-18$ & $5-12$ & $0-10$ \\
\hline SB15 & 154 & $8-20$ & $5-10$ & $0-8$ \\
\hline SB16 & 24 & $8-12$ & $5-9$ & $3-9$ \\
\hline SB17 & 3 & $8-9$ & $5-6$ & $8-9$ \\
\hline \hline
\end{tabular}

${ }^{\dagger}$ Note that this number only includes frit compositions that gave projected operating windows of at least 35-45\% WL for all three of the SRAT batches (beginning, middle, and end of processing) evaluated for each sludge batch.

The outcomes of the Nominal Stage assessments in Table 3-2 show mixed results in terms of the anticipated ability to process each sludge batch. A sufficient number of frits are available for SB9 through SB16 to indicate that, given the multiple assumptions made in this study, ${ }^{\mathrm{a}}$ a viable frit could be identified for the processing of these sludge batches. A very small number of frits are available for SB8 and SB17 (one frit and three frits, respectively), indicating that it may be possible to process these sludge batches, but there would be little or no opportunity for optimization of a frit composition. The ability to accommodate expected variation in the sludge batch composition would also be questionable.

SB8 then was studied further since only one frit composition was identified that gave a projected operating window of at least 35-45\% WL for all three (beginning, middle, and end of processing) SRAT batches when CST is added to Tank 40 (see Table 3-2). The individual Nominal Stage assessment results for each of the SB8 SRAT batches are given in Table 3-3. These data show that the number of frits providing a good projected operating window increases as SB8 is processed. This indicates that the sludge-only composition of SB8 is projected to be a difficult sludge to successfully process based on PCCS predictions (i.e., available frit compositions for producing a PCCS-acceptable glass are almost non-existent). As CST is added to Tank 40 during processing of SB8 (i.e., as the volume of sludge in Tank 40 is reduced), a larger number of frit compositions providing a good projected operating window become available due to the resulting change in composition.

\footnotetext{
${ }^{a}$ Several assumptions are associated with these results and the other outcomes presented in this section. These assumptions will be reviewed and discussed in Section 4.0.
} 
Table 3-3. MAR Assessment Results for SB8 with CST Additions to Tank 40 at 40 SRAT Batches Annually.

\begin{tabular}{||c|c||}
\hline Sludge Composition & $\begin{array}{c}\text { Number of frits providing } \\
\text { projected operating windows } \\
\text { of at least 35-45\% WL }\end{array}$ \\
\hline SB8, SRAT Batch 1 & 1 \\
\hline SB8, SRAT Batch 39 & 29 \\
\hline SB8, SRAT Batch 77 & 162 \\
\hline
\end{tabular}

A much larger array of potential frit compositions was developed for SB8 to gauge whether the addition of less common frit components or wider concentration ranges for the traditional frit components could provide better projected operating windows for this sludge batch projection. Concentration ranges for each of these components are listed in Table 3-4. The concentration of each component was varied in $1 \mathrm{wt} \%$ increments, resulting in a total of 245,700 potential frit compositions in the array.

Table 3-4. Concentration Ranges for Components of a Larger Frit Composition Array Used with SB8.

\begin{tabular}{||c|c||}
\hline Frit Oxide & $\begin{array}{c}\text { Concentration Range } \\
\text { (wt \%) }\end{array}$ \\
\hline $\mathrm{B}_{2} \mathrm{O}_{3}$ & $8-20$ \\
\hline $\mathrm{CaO}$ & $0-4$ \\
\hline $\mathrm{Fe}_{2} \mathrm{O}_{3}$ & $0-4$ \\
\hline $\mathrm{Li}_{2} \mathrm{O}$ & $4-12$ \\
\hline $\mathrm{MgO}$ & $0-1$ \\
\hline $\mathrm{Na}_{2} \mathrm{O}$ & $0-20$ \\
\hline $\mathrm{SiO}_{2}$ & $38-88$ \\
\hline $\mathrm{ZrO}_{2}$ & $0-1$ \\
\hline
\end{tabular}

The 245,700 frits outlined in Table 3-4 were combined with SRAT Batches 1 and 77 of SB8 (see Appendix A, Table A-1) over waste loadings of 35 to $45 \%$ for an additional Nominal Stage assessment. The results of this assessment are shown in Table 3-5. Only 10 frits from the larger array provide projected operating windows of at least $35-45 \%$ WL for SB8 SRAT Batch 1 . This further indicates that the sludge-only composition of SB8 presents a challenge for DWPF processing in terms of developing an optimal frit composition to produce a PCCS-acceptable glass while offering other properties such as improved melt rate or sulfur retention.

Table 3-5. MAR Assessment Results for SB8 with CST Additions to Tank 40 at 40 SRAT Batches Annually Using a Larger Frit Array.

\begin{tabular}{||c|c||}
\hline Sludge Composition & $\begin{array}{c}\text { Number of frits providing } \\
\text { projected operating windows } \\
\text { of at least 35-45\% WL }\end{array}$ \\
\hline SB8, SRAT Batch 1 & 10 \\
\hline SB8, SRAT Batch 77 & 4029 \\
\hline
\end{tabular}


Next, Sludge Batches 8, 16, and 17 were evaluated without the addition of SCIX streams to determine whether the compositions of the sludge batches alone, or the compositions with the SCIX streams added, were the cause of the small number of candidate frits providing reasonable projected operating windows. The sludge-only compositions for SB8, SB16, and SB17 are given in Appendix A, Table A-7. The results of Nominal Stage MAR assessments using the 1,144 frits outlined in Table 3-1 and these sludge-only compositions are given in Table 3-6.

Table 3-6. MAR Assessment Results for Sludge-Only Versions of SB8, SB16, and SB17.

\begin{tabular}{|c|c|c|c|c||}
\hline $\begin{array}{c}\text { Sludge } \\
\text { Batch }\end{array}$ & $\begin{array}{c}\text { Number of frits providing } \\
\text { projected operating windows of } \\
\text { at least 35-45\% WL }\end{array}$ & $\begin{array}{c}\text { Frit } \mathbf{B}_{\mathbf{2}} \mathbf{O}_{3} \\
\text { Range } \\
\text { (wt \%) }\end{array}$ & $\begin{array}{c}\text { Frit } \mathbf{L i}_{\mathbf{2}} \mathbf{O} \\
\text { Range } \\
\text { (wt \%) }\end{array}$ & $\begin{array}{c}\text { Frit } \mathbf{N a}_{2} \mathbf{O} \\
\text { Range } \\
\text { (wt \%) }\end{array}$ \\
\hline SB8 & 0 & n/a & n/a & n/a \\
\hline SB16 & 7 & $8-10$ & $5-6$ & $7-9$ \\
\hline SB17 & 0 & n/a & n/a & n/a \\
\hline
\end{tabular}

The results in Table 3-6 show that without the SCIX streams added, none of the candidate frits provided reasonable projected operating windows with SB8 or SB17. Only seven of the frits provided projected operating windows of at least 35-45\% WL for SB16. These results indicate that the issues with identifying candidate frits are related to the compositions of these individual sludge batches, rather than the addition of the SCIX streams. Sludge Batches 8, 16 and 17 should be further evaluated by SRR.

\subsubsection{CST to Tank 51 Option}

CST additions to Tank 51 at a processing rate of 40 SRAT batches per year were evaluated next. The results of Nominal Stage MAR assessments using the 1,144 frits outlined in Table 3-1 and the sludge compositions given in Appendix A, Table A-2, are given in Table 3-7. The number of frits available that provide projected operating windows of at least $35-45 \% \mathrm{WL}$ is listed for each sludge batch.

Table 3-7. MAR Assessment Results for CST Additions to Tank 51 at 40 SRAT Batches Annually.

\begin{tabular}{||c|c|c|c|c||}
\hline $\begin{array}{c}\text { Sludge } \\
\text { Batch }\end{array}$ & $\begin{array}{c}\text { Number of frits providing } \\
\text { projected operating windows of } \\
\text { at least 35-45\% WL }\end{array}$ & $\begin{array}{c}\text { Frit } \mathbf{B}_{2} \mathbf{O}_{3} \\
\text { Range } \\
\text { (wt \%) }\end{array}$ & $\begin{array}{c}\text { Frit } \mathbf{L i}_{2} \mathbf{O} \\
\text { Range } \\
\text { (wt \%) }\end{array}$ & $\begin{array}{c}\text { Frit } \mathbf{N a}_{2} \mathbf{O} \\
\text { Range } \\
\text { (wt \%) }\end{array}$ \\
\hline SB8 & 34 & $8-12$ & $5-9$ & $3-10$ \\
\hline SB9 & 156 & $8-19$ & $5-10$ & $0-9$ \\
\hline SB10 & 133 & $8-20$ & $5-10$ & $0-8$ \\
\hline SB11 & 131 & $8-16$ & $5-10$ & $0-9$ \\
\hline SB12 & 343 & $8-20$ & $5-12$ & $0-10$ \\
\hline SB13 & 385 & $8-20$ & $5-12$ & $0-10$ \\
\hline SB14 & 276 & $8-20$ & $5-12$ & $0-10$ \\
\hline SB15 & 220 & $8-20$ & $5-11$ & $0-9$ \\
\hline SB16 & 78 & $8-14$ & $5-11$ & $0-10$ \\
\hline SB17 & 23 & $8-12$ & $5-8$ & $5-10$ \\
\hline
\end{tabular}

The results in Table 3-7 indicate that a reasonable number of candidate frit compositions are available for each sludge batch when CST is added to Tank 51 at the 40 SRAT batches per year 
processing rate. SB8 and SB17 are the most challenging in that they have the fewest number of frits available providing projected operating windows of at least $35-45 \% \mathrm{WL}$, although there are likely enough frit compositions available to select a viable option for producing a PCCSacceptable glass.

\subsection{Outcome for TAR Task 2}

\subsubsection{CST to Tank 40 Option}

CST additions to Tank 40 with SWPF streams at a production rate of 75 SRAT batches per year were evaluated first for TAR Task 2. The results of Nominal Stage MAR assessments using the 1,144 frits described in Table 3-1 and the sludge compositions given in Appendix A, Table A-3, are given in Table 3-8. The number of frits available that provide projected operating windows of at least $35-45 \%$ WL is listed for each sludge batch. Note that this number only includes frit compositions that gave projected operating windows of 35-45\% WL for all three of the SRAT batches (beginning, middle, and end of processing) evaluated for each sludge batch.

Table 3-8. MAR Assessment Results for CST Additions to Tank 40 with SWPF Streams at 75 SRAT Batches Annually.

\begin{tabular}{|c|c|c|c|c|}
\hline $\begin{array}{c}\text { Sludge } \\
\text { Batch }\end{array}$ & $\begin{array}{c}\text { Number of frits providing } \\
\text { projected operating window of } \\
\text { at least 35-45\% WL } \mathbf{W L}^{\dagger}\end{array}$ & $\begin{array}{c}\mathbf{F r i t}_{\mathbf{~}} \mathbf{O}_{\mathbf{3}} \\
\text { Range } \\
\text { (wt \%) }\end{array}$ & $\begin{array}{c}\text { Frit } \mathbf{L i}_{2} \mathbf{O} \\
\text { Range } \\
\text { (wt \%) }\end{array}$ & $\begin{array}{c}\text { Frit } \mathbf{~ N a}_{2} \mathbf{O} \\
\text { Range } \\
\text { (wt \%) }\end{array}$ \\
\hline SB8 & 90 & $8-16$ & $5-10$ & $0-9$ \\
\hline SB9 & 102 & $8-20$ & $5-9$ & $0-8$ \\
\hline SB10 & 87 & $8-19$ & $5-9$ & $0-7$ \\
\hline SB11 & 127 & $8-20$ & $5-10$ & $0-8$ \\
\hline SB12 & 278 & $8-20$ & $5-12$ & $0-10$ \\
\hline SB13 & 296 & $8-20$ & $5-12$ & $0-9$ \\
\hline SB14 & 235 & $8-20$ & $5-11$ & $0-10$ \\
\hline SB15 & 158 & $8-20$ & $5-10$ & $0-8$ \\
\hline SB16 & 155 & $8-20$ & $5-10$ & $0-9$ \\
\hline SB17 & 117 & $5-10$ & $0-9$ \\
\hline
\end{tabular}

${ }^{\dagger}$ Note that this number only includes frit compositions that gave projected operating windows of at least 35-45\% WL for all three of the SRAT batches (beginning, middle, and end of processing) evaluated for each sludge batch.

The results in Table 3-8 indicate that a reasonable number of candidate frit compositions are available for each sludge batch when CST is added to Tank 40 at the 75 SRAT batches per year production rate with SWPF streams included. In particular, many more frits are available for processing SB8, SB16, and SB17 under these conditions, as compared to the Task 1 results.

\subsubsection{CST to Tank 51 Option}

CST additions to Tank 51 with SWPF streams at a production rate of 75 SRAT batches per year were evaluated next. The results of Nominal Stage MAR assessments using the 1,144 frits described in Table 3-1 and the sludge compositions given in Appendix A, Table A-4, are given in Table 3-9. The number of frits available that provide projected operating windows of at least 35$45 \% \mathrm{WL}$ is listed for each sludge batch. 
Table 3-9. MAR Assessment Results for CST Additions to Tank 51 with SWPF Streams at 75 SRAT Batches Annually.

\begin{tabular}{|c|c|c|c|c||}
\hline $\begin{array}{c}\text { Sludge } \\
\text { Batch }\end{array}$ & $\begin{array}{c}\text { Number of frits providing } \\
\text { projected operating windows of } \\
\text { at least 35-45\% WL }\end{array}$ & $\begin{array}{c}\text { Frit } \mathbf{B}_{2} \mathbf{O}_{3} \\
\text { Range } \\
\text { (wt \%) }\end{array}$ & $\begin{array}{c}\text { Frit } \mathbf{L i}_{2} \mathbf{O} \\
\text { Range } \\
\text { (wt \%) }\end{array}$ & $\begin{array}{c}\text { Frit } \mathbf{~ N a}_{2} \mathbf{O} \\
\text { Range } \\
\text { (wt \%) }\end{array}$ \\
\hline SB8 & 126 & $8-18$ & $5-10$ & $0-9$ \\
\hline SB9 & 140 & $8-20$ & $5-10$ & $0-8$ \\
\hline SB10 & 117 & $8-20$ & $5-9$ & $0-8$ \\
\hline SB11 & 155 & $8-20$ & $5-10$ & $0-9$ \\
\hline SB12 & 311 & $8-20$ & $5-12$ & $0-10$ \\
\hline SB13 & 335 & $8-20$ & $5-12$ & $0-10$ \\
\hline SB14 & 272 & $8-20$ & $5-12$ & $0-10$ \\
\hline SB15 & 203 & $8-20$ & $5-11$ & $0-8$ \\
\hline SB16 & 149 & $8-20$ & $5-10$ & $0-8$ \\
\hline SB17 & 138 & $5-10$ & $0-8$ \\
\hline
\end{tabular}

The results in Table 3-9 indicate that a reasonable number of candidate frit compositions are available for each sludge batch when CST is added to Tank 51 at the 75 SRAT batches per year production rate with SWPF streams included. In particular, many more frits are available for processing SB8, SB16, and SB17 under these conditions, as compared to the Task 1 results.

\subsubsection{Options with and without SWPF Streams}

An additional series of Nominal Stage MAR assessments was completed as part of Task 2 to evaluate the ability of candidate frits to provide useful projected operating windows for the sludge batches both with and without the inclusion of SWPF streams. The intent was to identify viable frits for the potential scenario where SWPF streams would be incorporated at varying volumes during the processing of a sludge batch. Sludge batch projections for CST added to Tank 40 without SWPF streams at the 75 SRAT batches per year production rate are given in Appendix A, Table A-5. The results of Nominal Stage MAR assessments using these sludge compositions, as well as the corresponding sludge compositions with SWPF included (Appendix A, Table A-3), and the 1,144 frits described in Table 3-1 are given in Table 3-10. The number of frits available that provide projected operating windows of at least 35-45\% WL, both with and without SWPF, is listed for each sludge batch. 
Table 3-10. MAR Assessment Results for CST Additions to Tank 40 with and without SWPF Streams at 75 SRAT Batches Annually.

\begin{tabular}{|c|c|c|c|c|}
\hline $\begin{array}{l}\text { Sludge } \\
\text { Batch }\end{array}$ & $\begin{array}{l}\text { Number of frits providing } \\
\text { projected operating window of } \\
\text { at least } 35-45 \% \mathrm{WL}^{\dagger}\end{array}$ & $\begin{array}{c}\text { Frit } \mathrm{B}_{2} \mathrm{O}_{3} \\
\text { Range } \\
\text { (wt \%) }\end{array}$ & $\begin{array}{c}\text { Frit } \mathrm{Li}_{2} \mathrm{O} \\
\text { Range } \\
\text { (wt \%) }\end{array}$ & $\begin{array}{c}\text { Frit } \mathrm{Na}_{2} \mathrm{O} \\
\text { Range } \\
\text { (wt \%) }\end{array}$ \\
\hline SB8 & 0 & $\mathrm{n} / \mathrm{a}$ & $\mathrm{n} / \mathrm{a}$ & $\mathrm{n} / \mathrm{a}$ \\
\hline SB9 & 51 & $8-14$ & $5-9$ & $0-8$ \\
\hline SB10 & 53 & $8-14$ & 5-9 & $\begin{array}{l}0-7 \\
\end{array}$ \\
\hline SB11 & 44 & $8-13$ & 5-10 & $0-8$ \\
\hline SB12 & 137 & $8-17$ & 5-12 & $0-10$ \\
\hline SB13 & 185 & $8-17$ & $5-12$ & $0-9$ \\
\hline SB14 & 103 & $8-16$ & $5-11$ & $0-10$ \\
\hline SB15 & 147 & $8-20$ & $5-10$ & $0-8$ \\
\hline SB16 & 8 & $8-10$ & $5-7$ & $6-9$ \\
\hline SB17 & 0 & $\mathrm{n} / \mathrm{a}$ & $\mathrm{n} / \mathrm{a}$ & $\mathrm{n} / \mathrm{a}$ \\
\hline
\end{tabular}

${ }^{\dagger}$ Note that this number only includes frit compositions that gave projected operating windows of at least 35-45\% WL for all three of the SRAT batches (beginning, middle, and end of processing) evaluated for each sludge batch, both with and without SWPF streams.

The results in Table 3-10 show that none of the candidate frit compositions evaluated provided projected operating windows of at least $35-45 \%$ WL for SB8 or SB17 when CST is added to Tank 40, both with and without SWPF streams, at 75 SRAT batches per year. The number of candidate frits available for SB16 with these conditions is very limited, while a reasonable number of frits are available for the other sludge batches.

Sludge batch projections for CST added to Tank 51 without SWPF streams at the 75 SRAT batches per year production rate are given in Appendix A, Table A-6. The results of Nominal Stage MAR assessments using these sludge compositions, as well as the corresponding sludge compositions with SWPF included (Appendix A, Table A-4), and the 1,144 frits described in Table 3-1 are given in Table 3-11. The number of frits available that provide projected operating windows of at least 35-45\% WL, both with and without SWPF, is listed for each sludge batch.

Table 3-11. MAR Assessment Results for CST Additions to Tank 51 with and without SWPF Streams at 75 SRAT Batches Annually.

\begin{tabular}{|c|c|c|c|c||}
\hline $\begin{array}{c}\text { Sludge } \\
\text { Batch }\end{array}$ & $\begin{array}{c}\text { Number of frits providing } \\
\text { projected operating windows of } \\
\text { at least 35-45\% WL }\end{array}$ & $\begin{array}{c}\text { Frit } \mathbf{B}_{\mathbf{2}} \mathbf{O}_{3} \\
\text { Range } \\
\text { (wt \%) }\end{array}$ & $\begin{array}{c}\text { Frit } \mathbf{L i}_{2} \mathbf{O} \\
\text { Range } \\
\text { (wt \%) }\end{array}$ & $\begin{array}{c}\text { Frit } \mathbf{~ N a}_{2} \mathbf{O} \\
\text { Range } \\
\text { (wt \%) }\end{array}$ \\
\hline SB8 & 7 & $8-10$ & $5-7$ & $6-9$ \\
\hline SB9 & 106 & $8-16$ & $5-10$ & $0-8$ \\
\hline SB10 & 108 & $8-17$ & $5-9$ & $0-8$ \\
\hline SB11 & 86 & $8-15$ & $5-10$ & $0-9$ \\
\hline SB12 & 212 & $8-19$ & $5-12$ & $0-10$ \\
\hline SB13 & 269 & $8-20$ & $5-12$ & $0-10$ \\
\hline SB14 & $171-18$ & $5-12$ & $0-10$ \\
\hline SB15 & 198 & $8-20$ & $5-11$ & $0-8$ \\
\hline SB16 & 23 & $8-12$ & $5-8$ & $3-8$ \\
\hline SB17 & 1 & 8 & 5 & 8 \\
\hline
\end{tabular}


The results in Table 3-11 show that SB8 and SB17 would be difficult to successfully process through PCCS (in terms of the number of candidate frits available) when CST is added to Tank 51, both with and without SWPF streams, at 75 SRAT batches per year. A reasonable number of candidate frits are available for the other sludge batches with these conditions.

\subsection{Chemical Process Cell Impacts}

The impact of additions of MST and/or CST on the DWPF CPC is expected to be minor as previously documented. $^{3}$ The amount of additional anions will not significantly impact the acid demand and will not impact the ability to control the glass reduction/oxidation potential using the ratio of nitric acid to formic acid. Two potential issues were identified in the previous review, and are described below.

\subsubsection{Yield Stress}

The CST solids will be ground prior to transfer to DWPF to a particle size similar to the HLW sludge (5-20 microns). The yield stress of the DWPF process slurries could be impacted if the rheological behavior of the CST solids is different than the sludge. ${ }^{19}$ Experimental testing would be required to evaluate the impact of using CST that has been ground in a prototypical manner.

\subsubsection{Hydrogen Generation}

SRNL performed experimental testing to determine the impact of MST on hydrogen generation during the SRAT/SME cycle ${ }^{20}$ as recommended by the Hydrogen Review Panel in March 2007. ${ }^{21}$ This evaluation, along with simulant testing, ${ }^{22}$ demonstrated that the CPC process could accommodate the MST stream. The MST component of the SCIX is expected to be similar to the MST from the ARP process, and no issues are expected during processing.

Additional testing is required to evaluate the impact of CST on hydrogen generation. Testing with simulants will demonstrate that the CST will not act as a catalytic substrate for increased noble metal reactions with formic acid. A test in the Shielded Cells with actual tank samples should be performed to address the concerns raised by the review panel that the CST could become catalytically active once exposed to radioactive species. 


\subsection{Conclusions and Recommendations}

This paper study evaluated composition projections for SB8 through SB17 with MST added during batch preparation and with CST added to either Tank 40 or Tank 51. Additions of CST to Tank 40 were made incrementally during processing, while additions of CST to Tank 51 were made in a single transfer. Two production rates were evaluated, along with the inclusion or exclusion of SWPF streams. The sludge compositions (a total of 120) were evaluated with an array of 1,144 candidate frit compositions using Nominal Stage MAR assessments with the DWPF PCCS models.

Several important assumptions had to be made in performing the evaluations described in this report:

- The composition projections for the sludge batches, MST additions, CST additions, and SWPF additions were considered to be the best available at the time of the study, although they are likely to change significantly.

- Sulfate concentrations were not provided for the sludge compositions used in Task 2 of the study.

- No attempt was made to evaluate the addition of streams from Tank 48 fluidized bed steam reforming treatment since the composition of the stream to be transferred to DWPF has not been sufficiently defined.

- MST, CST, and SWPF additions were made based on the starting composition of each sludge batch. Any carry over of material from these streams into the next sludge batch was not accounted for.

- It was assumed that the SWPF additions bound any additions from the ARP/MCU prior to the startup of SWPF.

- Each sludge batch was assumed to process until a heel of approximately 40 inches (or approximately 600,000 kg of sludge slurry) remained in Tank 40, including SB17.

- The impacts of higher $\mathrm{Nb}_{2} \mathrm{O}_{5}, \mathrm{TiO}_{2}$, and $\mathrm{ZrO}_{2}$ concentrations on liquidus temperature, viscosity, and durability for DWPF glasses are not yet known. An experimental study is currently underway to address this issue. For the purposes of the paper studies described here, it was assumed that the current liquidus temperature and viscosity models correctly predict the properties of glasses with higher $\mathrm{Nb}_{2} \mathrm{O}_{5}, \mathrm{TiO}_{2}$, and $\mathrm{ZrO}_{2}$ concentrations.

- A $2 \mathrm{wt} \% \mathrm{TiO}_{2}$ PAR limit is currently incorporated in PCCS. This limit was ignored for the purposes of this study since the $\mathrm{TiO}_{2}$ concentrations in many of the sludge composition projections evaluated here result in $\mathrm{TiO}_{2}$ concentrations in glass that are considerably higher than 2 wt \%.

- The updated $\Delta \mathrm{G}_{\mathrm{i}}$ term for $\mathrm{Nb}_{2} \mathrm{O}_{5}$ was not used in this study since $\mathrm{Nb}$ has not yet been incorporated as a reportable element in PCCS. Since the revised term for $\mathrm{Nb}_{2} \mathrm{O}_{5}$ is more positive than the previous term and indicates better durability $(+33.18 \mathrm{kcal} / \mathrm{mole}$ compared to $+2.93 \mathrm{kcal} /$ mole), the predicted impact of $\mathrm{Nb}_{2} \mathrm{O}_{5}$ on durability in this study was considered to be conservative. The experimental studies currently underway will further verify this term.

- No insight into anticipated melt rates is provided through these paper studies.

The results of the paper studies, whose utility must be considered carefully given the assumptions above, provided several observations:

- There was difficulty in identifying a reasonable number of candidate frits (and in some cases an inability to identify any candidate frits) when a waste loading of $40 \%$ is targeted for Sludge Batches 8, 16, and 17, regardless of the addition of SCIX or SWPF streams. 
This indicates that the blending strategy for these sludge batches should be reevaluated by SRR.

- In general, candidate frits were available to accommodate CST additions to either Tank 40 or Tank 51. A larger number of candidate frits were typically available for the sludge batches when CST is added to Tank 51 rather than Tank 40, meaning that more compositional flexibility would be available for frit selection and DWPF operation. Note however that for SB8 and SB17, no candidate frits were available to accommodate CST going to Tank 40 with and without SWPF streams.

- A reasonable number of candidate frits were available for most of the sludge batches when CST is added to either Tank 40 or Tank 51, with or without SWPF streams added. The addition of SWPF streams generally improves the number of candidate frits available for processing of a given sludge batch.

- The change in production rate from 40 SRAT batches per year to 75 SRAT batches per year, without SWPF streams included, had varied results in terms of the number of candidate frits available for processing of a given sludge batch. Therefore, this variable is not of much concern in terms of incorporating the SCIX streams.

A review of CPC processing identified no changes to the recommendations from the previous review of the SCIX process impacts. Recommendations for testing were made during the previous review to evaluate the impact of CST on the rheological properties of DWPF process streams and to evaluate the impact of CST on catalytic hydrogen generation during CPC processing.

Overall, the outcome of this study shows no major issues with CST from the SCIX process going to either Tank 40 or Tank 51. The assumptions used and the model limitations that have been identified must be addressed through further experimental studies. As changes occur to the planned additions of MST and CST, or to the sludge batch preparation strategy, additional evaluations will be performed to determine the potential impacts. The issues with individual Sludge Batches 8, 16, and 17 should be further evaluated by SRR. 


\subsection{References}

1. Tran, H., "Preliminary Flowsheet for Crystalline Silicotitanate Small Column Ion-Exchange Processing of Tanks 1, 2, 3, 37 and 41 Dissolved Salts," U.S. Department of Energy Report LWO-LWE-2007-00178, Revision 0, Washington Savannah River Company, Aiken, SC (2007).

2. Peeler, D. K. and T. B. Edwards, "High-Level Review of the Impacts of CST and RF on DWPF Processing: A Glass Formulation Perspective,” U.S. Department of Energy Report SRNLPSE-2007-00177, Washington Savannah River Company, Aiken, SC (2007).

3. Stone, M. E., "Estimation of Modular Salt Processing Impact on DWPF CPC Process," U.S. Department of Energy Report SRNL-PSE-2007-00216, Savannah River National Laboratory, Aiken, SC (2007).

4. Fellinger, T. L., "Technical Assistance Request: Perform Impact Analyses for Introduction of Modular Salt Processing Streams to DWPF," U.S. Department of Energy Report HLW-DWPFTAR-2010-0009, Revision A, Savannah River Remediation, Aiken, SC (2010).

5. Maxwell, D., "Preliminary Modular Salt Processing Flowsheet for Addition of Modified Monosodium Titanate and Operation of the Rotary Microfilter," U.S. Department of Energy Report LWO-LWE-2007-00174, Revision 0, Washington Savannah River Company, Aiken, SC (2007).

6. Chew, D. P. and B. A. Hamm, "Liquid Waste System Plan,” U.S. Department of Energy Report SRR-LWP-2009-00001, Revision 15, Savannah River Remediation, Aiken, SC (2010).

7. Samadi, A., "Input Sheet for DWPF Coal WAC Limit Evaluation (Tank 48 Impact Study)," U.S. Department of Energy Report SRR-SPT-2010-00010, Revision 0, Savannah River Remediation, Aiken, SC (2010).

8. Peeler, D. K. and T. B. Edwards, "Frit Development Effort for SB4: Nominal and Variation Stage Assessments,” U.S. Department of Energy Report WSRC-TR-2005-00372, Revision 0, Westinghouse Savannah River Company, Aiken, SC (2005).

9. Brown, K. G., C. M. Jantzen and G. Ritzhaupt, "Relating Liquidus Temperature to Composition for Defense Waste Processing Facility (DWPF) Process Control," U.S. Department of Energy Report WSRC-TR-2001-00520, Revision 0, Westinghouse Savannah River Company, Aiken, SC (2001).

10. Jantzen, C. M., "The Impacts of Uranium and Thorium on the Defense Waste Processing Facility (DWPF) Viscosity Model,” U.S. Department of Energy Report WSRC-TR-2004-00311, Revision 0, Westinghouse Savannah River Company, Aiken, SC (2005).

11. Edwards, T. B., D. K. Peeler and K. M. Fox, "The Nepheline Discriminator: Justification and DWPF PCCS Implementation Details,” U.S. Department of Energy Report WSRC-STI-200600014, Revision 0, Washington Savannah River Company, Aiken, SC (2006).

12. ASTM, "Standard Test Methods for Determining Chemical Durability of Nuclear Waste Glasses: The Product Consistency Test (PCT)”, ASTM C-1285, (2002). 
13. Jantzen, C. M., J. B. Picket, K. G. Brown, T. B. Edwards and D. C. Beam, "Process/Product Models for the Defense Waste Processing Facility (DWPF): Part I. Predicting Glass Durability from Composition Using a Thermodynamic Hydration Energy Reaction Model (THERMO)," U.S. Department of Energy Report WSRC-TR-93-672, Revision 1, Westinghouse Savannah River Company, Aiken, SC (1995).

14. Lorier, T. H. and C. M. Jantzen, "Evaluation of the $\mathrm{TiO}_{2}$ Limit for DWPF Glass," U.S. Department of Energy Report WSRC-TR-2003-00396, Revision 0, Westinghouse Savannah River Company, Aiken, SC (2003).

15. Jantzen, C. M., "Free Energy of Hydration of Niobium Oxide," U.S. Department of Energy Report SRNL-TR-2010-00125, Revision 0, Savannah River National Laboratory, Aiken, SC (2010).

16. Plodinec, M. J., "Free Energy of Hydration of Niobium Oxide," U.S. Department of Energy Report WSRC-RD-96-011, Revision 0, Westinghouse Savannah River Company, Aiken, SC (1996).

17. Fellinger, T. L., "Technical Task Request: DWPF Glass Evaluation for the Introduction of MSP Products into Future Sludge Batches," U.S. Department of Energy Report HLW-DWPFTTR-2010-0009, Revision A, Savannah River Remediation, Aiken, SC (2010).

18. Fox, K. M., "Task Technical and Quality Assurance Plan for Evaluation of the Introduction of Modular Salt Processing Products to Defense Waste Processing Facility Glass for Future Sludge Batches," U.S. Department of Energy Report SRNL-RP-2010-00560, Revision 0, Savannah River National Laboratory, Aiken, SC (2010).

19. Hansen, E. K., D. C. Koopman and P. R. Monson, "Impact of CST on the Rheological Characteristics of DWPF Melter Feed,” U.S. Department of Energy Report WSRC-TR-200100069, Revision 0, Westinghouse Savannah River Company, Aiken, SC (2001).

20. Lambert, D. P., J. M. Pareizs, B. R. Pickenheim, C. J. Bannochie, M. E. Stone, D. R. Click, E. K. Hansen, K. P. Crapse and D. T. Hobbs, "Demonstration of the DWPF Flowsheet in the SRNL Shielded Cells Using ARP Product Simulant and SB4 Tank 40 Sludge Slurry,” U.S. Department of Energy Report WSRC-STI-2008-00130, Revision 0, Washington Savannah River Company, Aiken, SC (2008).

21. Plodinec, M. J., "Report of the Hydrogen Generation Review Panel - Review of Hydrogen Generation in the DWPF,” U.S. Department of Energy Report (2007).

22. Baich, M. A., C. C. Herman, R. E. Eibling, M. F. Williams and F. G. Smith, "Sludge Batch 4 Simulant Flowsheet Studies with ARP and MCU: Impact of MCU Organics," U.S. Department of Energy Report WSRC-TR-2005-00230, Revision 0, Westinghouse Savannah River Company, Aiken, SC (2005). 
SRNL-STI-2010-00297

Revision 0

Appendix A 
Table A-1. Composition Projections for CST Added to Tank 40 without SWPF Streams at 40 SRAT Batches Annually.

\begin{tabular}{|c|c|c|c|c|c|c|c|c|c|}
\hline "Sludge Batch & \multicolumn{3}{|c|}{ SB8 } & \multicolumn{3}{|c|}{ SB9 } & \multicolumn{3}{|c|}{ SB10 } \\
\hline SRAT Batch & 1 & 39 & 77 & 1 & 45 & 89 & 1 & 45 & 90 \\
\hline $\mathrm{Al}_{2} \mathrm{O}_{3}$ & 16.27 & 15.18 & 13.34 & 14.41 & 13.31 & 11.40 & 11.91 & 10.99 & 9.40 \\
\hline $\mathrm{BaO}$ & 0.23 & 0.22 & 0.19 & 0.22 & 0.21 & 0.18 & 0.25 & 0.23 & 0.19 \\
\hline $\mathrm{CaO}$ & 3.09 & 2.88 & 2.53 & 3.12 & 2.88 & 2.47 & 3.08 & 2.84 & 2.43 \\
\hline $\mathrm{Ce}_{2} \mathrm{O}_{3}$ & 0.98 & 0.92 & 0.80 & 0.90 & 0.83 & 0.71 & 0.86 & 0.79 & 0.68 \\
\hline $\mathrm{Cr}_{2} \mathrm{O}_{3}$ & 0.23 & 0.21 & 0.19 & 0.26 & 0.24 & 0.21 & 0.28 & 0.26 & 0.22 \\
\hline $\mathrm{CuO}$ & 0.07 & 0.07 & 0.06 & 0.08 & 0.07 & 0.06 & 0.08 & 0.07 & 0.06 \\
\hline $\mathrm{Fe}_{2} \mathrm{O}_{3}$ & 40.05 & 37.36 & 32.84 & 37.99 & 35.07 & 30.04 & 37.46 & 34.57 & 29.55 \\
\hline $\mathrm{K}_{2} \mathrm{O}$ & 0.15 & 0.14 & 0.13 & 0.17 & 0.16 & 0.13 & 0.18 & 0.17 & 0.14 \\
\hline $\mathrm{La}_{2} \mathrm{O}_{3}$ & 0.31 & 0.29 & 0.26 & 0.29 & 0.27 & 0.23 & 0.28 & 0.26 & 0.22 \\
\hline $\mathrm{MgO}$ & 0.54 & 0.50 & 0.44 & 0.53 & 0.49 & 0.42 & 0.51 & 0.47 & 0.41 \\
\hline $\mathrm{MnO}$ & 6.38 & 5.95 & 5.23 & 5.60 & 5.17 & 4.43 & 5.89 & 5.44 & 4.65 \\
\hline $\mathrm{Na}_{2} \mathrm{O}$ & 23.32 & 23.04 & 22.57 & 26.29 & 25.74 & 24.80 & 26.89 & 26.30 & 25.26 \\
\hline $\mathrm{Nb}_{2} \mathrm{O}_{5}$ & 0.03 & 1.38 & 3.65 & 0.03 & 1.57 & 4.23 & 0.03 & 1.57 & 4.27 \\
\hline $\mathrm{NiO}$ & 1.10 & 1.03 & 0.90 & 0.60 & 0.55 & 0.47 & 0.97 & 0.89 & 0.76 \\
\hline $\mathrm{PbO}$ & 0.50 & 0.47 & 0.41 & 0.44 & 0.41 & 0.35 & 0.42 & 0.39 & 0.33 \\
\hline $\mathrm{SiO}_{2}$ & 1.77 & 2.80 & 4.52 & 3.34 & 4.40 & 6.21 & 3.83 & 4.85 & 6.62 \\
\hline $\mathrm{SO}_{4}{ }^{2-}$ & 0.06 & 0.06 & 0.05 & 0.15 & 0.14 & 0.12 & 0.18 & 0.17 & 0.14 \\
\hline $\mathrm{ThO}_{2}$ & 0.61 & 0.56 & 0.50 & 2.05 & 1.89 & 1.62 & 2.89 & 2.67 & 2.28 \\
\hline $\mathrm{TiO}_{2}$ & 1.75 & 3.58 & 6.65 & 1.74 & 3.83 & 7.44 & 1.75 & 3.84 & 7.49 \\
\hline $\mathrm{U}_{3} \mathrm{O}_{8}$ & 1.86 & 1.74 & 1.53 & 1.08 & 0.99 & 0.85 & 1.55 & 1.43 & 1.22 \\
\hline $\mathrm{ZnO}$ & 0.06 & 0.06 & 0.05 & 0.06 & 0.06 & 0.05 & 0.07 & 0.07 & 0.06 \\
\hline $\mathrm{ZrO}_{2}$ & 0.62 & 1.57 & 3.16 & 0.63 & 1.71 & 3.58 & 0.64 & 1.73 & 3.61 \\
\hline
\end{tabular}


Table A-1. Composition Projections for CST Added to Tank 40 without SWPF Streams at 40 SRAT Batches Annually. (continued)

\begin{tabular}{|c|c|c|c|c|c|c|c|c|c|}
\hline Sludge Batch & \multicolumn{3}{|c|}{ SB11 } & \multicolumn{3}{|c|}{ SB12 } & \multicolumn{3}{|c|}{ SB13 } \\
\hline SRAT Batch & 1 & 39 & 78 & 1 & 40 & 79 & 1 & 37 & 74 \\
\hline $\mathrm{Al}_{2} \mathrm{O}_{3}$ & 13.70 & 12.79 & 11.23 & 20.10 & 18.73 & 16.43 & 21.15 & 19.78 & 17.43 \\
\hline $\mathrm{BaO}$ & 0.21 & 0.20 & 0.17 & 0.23 & 0.22 & 0.19 & 0.23 & 0.22 & 0.19 \\
\hline $\mathrm{CaO}$ & 2.89 & 2.70 & 2.37 & 3.15 & 2.94 & 2.58 & 3.21 & 3.00 & 2.64 \\
\hline $\mathrm{Ce}_{2} \mathrm{O}_{3}$ & 0.76 & 0.71 & 0.62 & 0.47 & 0.44 & 0.38 & 0.30 & 0.28 & 0.25 \\
\hline $\mathrm{Cr}_{2} \mathrm{O}_{3}$ & 0.34 & 0.31 & 0.28 & 0.38 & 0.35 & 0.31 & 0.39 & 0.37 & 0.33 \\
\hline $\mathrm{CuO}$ & 0.08 & 0.07 & 0.06 & 0.11 & 0.11 & 0.09 & 0.14 & 0.13 & 0.11 \\
\hline $\mathrm{Fe}_{2} \mathrm{O}_{3}$ & 40.36 & 37.68 & 33.08 & 32.40 & 30.20 & 26.49 & 29.99 & 28.05 & 24.73 \\
\hline $\mathrm{K}_{2} \mathrm{O}$ & 0.18 & 0.17 & 0.15 & 0.28 & 0.26 & 0.23 & 0.33 & 0.30 & 0.27 \\
\hline $\mathrm{La}_{2} \mathrm{O}_{3}$ & 0.26 & 0.24 & 0.21 & 0.20 & 0.19 & 0.16 & 0.16 & 0.15 & 0.14 \\
\hline $\mathrm{MgO}$ & 0.55 & 0.51 & 0.45 & 0.46 & 0.43 & 0.38 & 0.38 & 0.36 & 0.31 \\
\hline $\mathrm{MnO}$ & 3.56 & 3.33 & 2.92 & 3.48 & 3.24 & 2.84 & 3.91 & 3.66 & 3.23 \\
\hline $\mathrm{Na}_{2} \mathrm{O}$ & 25.42 & 25.01 & 24.30 & 25.43 & 25.00 & 24.28 & 25.14 & 24.75 & 24.09 \\
\hline $\mathrm{Nb}_{2} \mathrm{O}_{5}$ & 0.03 & 1.36 & 3.65 & 0.03 & 1.39 & 3.70 & 0.03 & 1.33 & 3.56 \\
\hline $\mathrm{NiO}$ & 0.51 & 0.47 & 0.42 & 0.34 & 0.32 & 0.28 & 0.47 & 0.44 & 0.39 \\
\hline $\mathrm{PbO}$ & 0.36 & 0.33 & 0.29 & 0.23 & 0.21 & 0.19 & 0.17 & 0.16 & 0.14 \\
\hline $\mathrm{SiO}_{2}$ & 6.16 & 6.88 & 8.12 & 7.99 & 8.60 & 9.64 & 7.77 & 8.37 & 9.40 \\
\hline $\mathrm{SO}_{4}^{2-}$ & 0.48 & 0.45 & 0.39 & 0.39 & 0.36 & 0.32 & 0.36 & 0.34 & 0.30 \\
\hline $\mathrm{ThO}_{2}$ & 0.81 & 0.75 & 0.66 & 0.01 & 0.01 & 0.01 & 0.01 & 0.01 & 0.01 \\
\hline $\mathrm{TiO}_{2}$ & 1.74 & 3.54 & 6.65 & 1.74 & 3.58 & 6.71 & 1.78 & 3.54 & 6.55 \\
\hline $\mathrm{U}_{3} \mathrm{O}_{8}$ & 0.78 & 0.73 & 0.64 & 1.73 & 1.61 & 1.41 & 3.14 & 2.94 & 2.59 \\
\hline $\mathrm{ZnO}$ & 0.24 & 0.22 & 0.19 & 0.19 & 0.17 & 0.15 & 0.24 & 0.22 & 0.20 \\
\hline $\mathrm{ZrO}_{2}$ & 0.60 & 1.54 & 3.15 & 0.67 & 1.62 & 3.24 & 0.68 & 1.59 & 3.15 \\
\hline
\end{tabular}


Table A-1. Composition Projections for CST Added to Tank 40 without SWPF Streams at 40 SRAT Batches Annually. (continued)

\begin{tabular}{|c|c|c|c|c|c|c|c|c|c|}
\hline Sludge Batch & \multicolumn{3}{|c|}{ SB14 } & \multicolumn{3}{|c|}{ SB15 } & \multicolumn{3}{|c|}{ SB16 } \\
\hline SRAT Batch & 1 & 31 & 62 & 1 & 52 & 103 & 1 & 19 & 38 \\
\hline $\mathrm{Al}_{2} \mathrm{O}_{3}$ & 14.11 & 13.42 & 12.24 & 12.13 & 11.15 & 9.40 & 12.89 & 12.31 & 11.44 \\
\hline $\mathrm{BaO}$ & 0.27 & 0.26 & 0.23 & 0.26 & 0.24 & 0.20 & 0.24 & 0.23 & 0.22 \\
\hline $\mathrm{CaO}$ & 2.65 & 2.52 & 2.30 & 2.38 & 2.19 & 1.85 & 2.70 & 2.58 & 2.40 \\
\hline $\mathrm{Ce}_{2} \mathrm{O}_{3}$ & 0.22 & 0.21 & 0.19 & 0.26 & 0.24 & 0.20 & 0.62 & 0.59 & 0.55 \\
\hline $\mathrm{Cr}_{2} \mathrm{O}_{3}$ & 0.38 & 0.36 & 0.33 & 0.35 & 0.32 & 0.27 & 0.28 & 0.26 & 0.25 \\
\hline $\mathrm{CuO}$ & 0.13 & 0.12 & 0.11 & 0.11 & 0.10 & 0.09 & 0.10 & 0.10 & 0.09 \\
\hline $\mathrm{Fe}_{2} \mathrm{O}_{3}$ & 28.12 & 26.73 & 24.38 & 27.05 & 24.87 & 20.98 & 35.65 & 34.03 & 31.62 \\
\hline $\mathrm{K}_{2} \mathrm{O}$ & 0.27 & 0.25 & 0.23 & 0.22 & 0.20 & 0.17 & 0.19 & 0.18 & 0.17 \\
\hline $\mathrm{La}_{2} \mathrm{O}_{3}$ & 0.13 & 0.12 & 0.11 & 0.13 & 0.12 & 0.10 & 0.22 & 0.21 & 0.20 \\
\hline $\mathrm{MgO}$ & 0.33 & 0.32 & 0.29 & 0.32 & 0.29 & 0.24 & 0.36 & 0.35 & 0.32 \\
\hline $\mathrm{MnO}$ & 2.24 & 2.13 & 1.94 & 2.90 & 2.66 & 2.25 & 1.59 & 1.52 & 1.41 \\
\hline $\mathrm{Na}_{2} \mathrm{O}$ & 24.27 & 24.02 & 23.59 & 26.46 & 25.87 & 24.82 & 22.36 & 22.22 & 22.00 \\
\hline $\mathrm{Nb}_{2} \mathrm{O}_{5}$ & 0.03 & 1.02 & 2.70 & 0.03 & 1.64 & 4.53 & 0.04 & 0.95 & 2.31 \\
\hline $\mathrm{NiO}$ & 1.90 & 1.81 & 1.65 & 1.81 & 1.66 & 1.40 & 1.52 & 1.45 & 1.35 \\
\hline $\mathrm{PbO}$ & 0.20 & 0.19 & 0.18 & 0.24 & 0.22 & 0.18 & 0.40 & 0.38 & 0.35 \\
\hline $\mathrm{SiO}_{2}$ & 5.81 & 6.36 & 7.30 & 4.50 & 5.51 & 7.31 & 1.87 & 2.56 & 3.58 \\
\hline $\mathrm{SO}_{4}{ }^{2-}$ & 0.24 & 0.23 & 0.21 & 0.18 & 0.17 & 0.14 & 0.06 & 0.06 & 0.05 \\
\hline $\mathrm{ThO}_{2}$ & 0.02 & 0.02 & 0.02 & 0.00 & 0.00 & 0.00 & 0.00 & 0.00 & 0.00 \\
\hline $\mathrm{TiO}_{2}$ & 1.69 & 3.04 & 5.32 & 1.63 & 3.84 & 7.77 & 2.28 & 3.49 & 5.30 \\
\hline $\mathrm{U}_{3} \mathrm{O}_{8}$ & 16.18 & 15.38 & 14.02 & 18.34 & 16.86 & 14.23 & 15.89 & 15.17 & 14.10 \\
\hline $\mathrm{ZnO}$ & 0.21 & 0.20 & 0.18 & 0.17 & 0.16 & 0.14 & 0.14 & 0.13 & 0.12 \\
\hline $\mathrm{ZrO}_{2}$ & 0.60 & 1.30 & 2.48 & 0.55 & 1.69 & 3.73 & 0.58 & 1.22 & 2.18 \\
\hline
\end{tabular}


Table A-1. Composition Projections for CST Added to Tank 40 without SWPF Streams at 40 SRAT Batches Annually. (continued)

\begin{tabular}{|c|c|c|c|}
\hline Sludge Batch & \multicolumn{3}{|c|}{ SB17 } \\
\hline SRAT Batch & 1 & 20 & 39 \\
\hline $\mathrm{Al}_{2} \mathrm{O}_{3}$ & 13.19 & 12.59 & 11.73 \\
\hline $\mathrm{BaO}$ & 0.25 & 0.23 & 0.22 \\
\hline $\mathrm{CaO}$ & 2.82 & 2.69 & 2.51 \\
\hline $\mathrm{Ce}_{2} \mathrm{O}_{3}$ & 0.74 & 0.70 & 0.65 \\
\hline $\mathrm{Cr}_{2} \mathrm{O}_{3}$ & 0.25 & 0.24 & 0.22 \\
\hline $\mathrm{CuO}$ & 0.09 & 0.08 & 0.08 \\
\hline $\mathrm{Fe}_{2} \mathrm{O}_{3}$ & 38.59 & 36.84 & 34.33 \\
\hline $\mathrm{K}_{2} \mathrm{O}$ & 0.18 & 0.17 & 0.16 \\
\hline $\mathrm{La}_{2} \mathrm{O}_{3}$ & 0.25 & 0.23 & 0.22 \\
\hline $\mathrm{MgO}$ & 0.38 & 0.36 & 0.34 \\
\hline $\mathrm{MnO}$ & 1.17 & 1.12 & 1.04 \\
\hline $\mathrm{Na}_{2} \mathrm{O}$ & 21.07 & 20.98 & 20.86 \\
\hline $\mathrm{Nb}_{2} \mathrm{O}_{5}$ & 0.04 & 0.95 & 2.26 \\
\hline $\mathrm{NiO}$ & 1.42 & 1.36 & 1.26 \\
\hline $\mathrm{PbO}$ & 0.44 & 0.42 & 0.39 \\
\hline $\mathrm{SiO}_{2}$ & 1.02 & 1.74 & 2.79 \\
\hline $\mathrm{SO}_{4}{ }^{2-}$ & 0.03 & 0.03 & 0.03 \\
\hline $\mathrm{ThO}_{2}$ & 0.00 & 0.00 & 0.00 \\
\hline $\mathrm{TiO}_{2}$ & 2.18 & 3.40 & 5.14 \\
\hline $\mathrm{U}_{3} \mathrm{O}_{8}$ & 15.18 & 14.49 & 13.50 \\
\hline $\mathrm{ZnO}$ & 0.12 & 0.12 & 0.11 \\
\hline $\mathrm{ZrO}_{2}$ & 0.60 & 1.24 & 2.16 \\
\hline
\end{tabular}


Table A-2. Composition Projections for CST Added to Tank 51 without SWPF Streams at 40 SRAT Batches Annually.

\begin{tabular}{|c|c|c|c|c|c|c|c|c|c|c|}
\hline $\begin{array}{l}\text { Sludge } \\
\text { Batch }\end{array}$ & SB8 & SB9 & SB10 & SB11 & SB12 & SB13 & SB14 & SB15 & SB16 & SB17 \\
\hline $\mathrm{Al}_{2} \mathrm{O}_{3}$ & 14.93 & 13.05 & 10.74 & 12.56 & 18.44 & 19.45 & 12.94 & 10.93 & 12.12 & 12.45 \\
\hline $\mathrm{BaO}$ & 0.21 & 0.20 & 0.22 & 0.19 & 0.22 & 0.22 & 0.25 & 0.23 & 0.23 & 0.23 \\
\hline $\mathrm{CaO}$ & 2.83 & 2.83 & 2.78 & 2.65 & 2.89 & 2.95 & 2.43 & 2.15 & 2.54 & 2.66 \\
\hline $\mathrm{Ce}_{2} \mathrm{O}_{3}$ & 0.90 & 0.82 & 0.77 & 0.70 & 0.43 & 0.28 & 0.20 & 0.23 & 0.58 & 0.69 \\
\hline $\mathrm{Cr}_{2} \mathrm{O}_{3}$ & 0.21 & 0.24 & 0.25 & 0.31 & 0.35 & 0.36 & 0.35 & 0.32 & 0.26 & 0.23 \\
\hline $\mathrm{CuO}$ & 0.07 & 0.07 & 0.07 & 0.07 & 0.10 & 0.13 & 0.12 & 0.10 & 0.09 & 0.08 \\
\hline $\mathrm{Fe}_{2} \mathrm{O}_{3}$ & 36.74 & 34.38 & 33.78 & 37.00 & 29.72 & 27.59 & 25.80 & 24.37 & 33.52 & 36.43 \\
\hline $\mathrm{K}_{2} \mathrm{O}$ & 0.14 & 0.15 & 0.16 & 0.17 & 0.25 & 0.30 & 0.24 & 0.20 & 0.18 & 0.17 \\
\hline $\mathrm{La}_{2} \mathrm{O}_{3}$ & 0.29 & 0.27 & 0.25 & 0.24 & 0.18 & 0.15 & 0.12 & 0.12 & 0.21 & 0.23 \\
\hline $\mathrm{MgO}$ & 0.49 & 0.48 & 0.46 & 0.50 & 0.43 & 0.35 & 0.30 & 0.28 & 0.34 & 0.36 \\
\hline $\mathrm{MnO}$ & 5.85 & 5.07 & 5.31 & 3.27 & 3.19 & 3.60 & 2.05 & 2.61 & 1.50 & 1.11 \\
\hline $\mathrm{Na}_{2} \mathrm{O}$ & 23.09 & 25.74 & 26.26 & 25.02 & 25.02 & 24.77 & 23.96 & 25.86 & 22.28 & 21.07 \\
\hline $\mathrm{Nb}_{2} \mathrm{O}_{5}$ & 1.81 & 2.06 & 2.13 & 1.82 & 1.81 & 1.76 & 1.81 & 2.14 & 1.36 & 1.28 \\
\hline $\mathrm{NiO}$ & 1.01 & 0.54 & 0.87 & 0.47 & 0.32 & 0.43 & 1.74 & 1.63 & 1.43 & 1.34 \\
\hline $\mathrm{PbO}$ & 0.46 & 0.40 & 0.38 & 0.33 & 0.21 & 0.16 & 0.19 & 0.21 & 0.37 & 0.42 \\
\hline $\mathrm{SiO}_{2}$ & 3.14 & 4.75 & 5.24 & 7.16 & 8.84 & 8.62 & 6.84 & 5.85 & 2.87 & 2.01 \\
\hline $\mathrm{SO}_{4}^{2-}$ & 0.05 & 0.14 & 0.16 & 0.44 & 0.36 & 0.33 & 0.22 & 0.16 & 0.06 & 0.03 \\
\hline $\mathrm{ThO}_{2}$ & 0.56 & 1.86 & 2.61 & 0.74 & 0.01 & 0.01 & 0.02 & 0.00 & 0.00 & 0.00 \\
\hline $\mathrm{TiO}_{2}$ & 3.57 & 3.87 & 3.95 & 3.58 & 3.57 & 3.54 & 3.53 & 3.88 & 3.47 & 3.30 \\
\hline $\mathrm{U}_{3} \mathrm{O}_{8}$ & 1.71 & 0.97 & 1.40 & 0.71 & 1.58 & 2.89 & 14.84 & 16.53 & 14.94 & 14.33 \\
\hline $\mathrm{ZnO}$ & 0.06 & 0.06 & 0.07 & 0.22 & 0.17 & 0.22 & 0.19 & 0.16 & 0.13 & 0.12 \\
\hline $\mathrm{ZrO}_{2}$ & 1.87 & 2.06 & 2.12 & 1.86 & 1.92 & 1.90 & 1.86 & 2.04 & 1.51 & 1.47 \\
\hline
\end{tabular}


Table A-3. Composition Projections for CST Added to Tank 40 with SWPF Streams at 75 SRAT Batches Annually.

\begin{tabular}{|c|c|c|c|c|c|c|c|c|c|}
\hline Sludge Batch & \multicolumn{3}{|c|}{ SB8 } & \multicolumn{3}{|c|}{ SB9 } & \multicolumn{3}{|c|}{ SB10 } \\
\hline SRAT Batch & 1 & 35 & 69 & 1 & 40 & 79 & 1 & 40 & 80 \\
\hline $\mathrm{Al}_{2} \mathrm{O}_{3}$ & 16.31 & 15.55 & 14.25 & 14.60 & 13.91 & 12.68 & 12.45 & 11.88 & 10.85 \\
\hline $\mathrm{BaO}$ & 0.19 & 0.18 & 0.17 & 0.20 & 0.19 & 0.17 & 0.20 & 0.19 & 0.17 \\
\hline $\mathrm{CaO}$ & 2.68 & 2.54 & 2.30 & 2.71 & 2.57 & 2.31 & 2.71 & 2.57 & 2.32 \\
\hline $\mathrm{Ce}_{2} \mathrm{O}_{3}$ & 0.82 & 0.77 & 0.70 & 0.82 & 0.78 & 0.70 & 0.72 & 0.69 & 0.62 \\
\hline $\mathrm{Cr}_{2} \mathrm{O}_{3}$ & 0.25 & 0.24 & 0.22 & 0.26 & 0.24 & 0.22 & 0.26 & 0.24 & 0.22 \\
\hline $\mathrm{CuO}$ & 0.11 & 0.10 & 0.09 & 0.11 & 0.10 & 0.09 & 0.11 & 0.10 & 0.09 \\
\hline $\mathrm{Fe}_{2} \mathrm{O}_{3}$ & 34.60 & 32.81 & 29.72 & 33.08 & 31.34 & 28.22 & 32.61 & 30.94 & 27.86 \\
\hline $\mathrm{K}_{2} \mathrm{O}$ & 0.10 & 0.10 & 0.09 & 0.11 & 0.10 & 0.09 & 0.11 & 0.10 & 0.09 \\
\hline $\mathrm{La}_{2} \mathrm{O}_{3}$ & 0.31 & 0.29 & 0.26 & 0.21 & 0.20 & 0.18 & 0.21 & 0.20 & 0.18 \\
\hline $\mathrm{MgO}$ & 0.43 & 0.41 & 0.37 & 0.44 & 0.41 & 0.37 & 0.44 & 0.42 & 0.37 \\
\hline $\mathrm{MnO}$ & 5.51 & 5.22 & 4.73 & 4.88 & 4.63 & 4.17 & 5.12 & 4.86 & 4.37 \\
\hline $\mathrm{Na}_{2} \mathrm{O}$ & 25.69 & 25.47 & 25.08 & 28.07 & 27.71 & 27.05 & 28.55 & 28.17 & 27.47 \\
\hline $\mathrm{Nb}_{2} \mathrm{O}_{5}$ & 0.02 & 0.95 & 2.54 & 0.02 & 0.97 & 2.68 & 0.02 & 0.95 & 2.66 \\
\hline $\mathrm{NiO}$ & 1.00 & 0.95 & 0.86 & 0.56 & 0.53 & 0.48 & 0.90 & 0.85 & 0.77 \\
\hline $\mathrm{PbO}$ & 0.47 & 0.44 & 0.40 & 0.38 & 0.36 & 0.32 & 0.38 & 0.36 & 0.32 \\
\hline $\mathrm{SiO}_{2}$ & 1.51 & 2.21 & 3.43 & 2.84 & 3.49 & 4.68 & 3.41 & 4.02 & 5.15 \\
\hline $\mathrm{SO}_{4}{ }^{2-}$ & 0.00 & 0.00 & 0.00 & 0.00 & 0.00 & 0.00 & 0.00 & 0.00 & 0.00 \\
\hline $\mathrm{ThO}_{2}$ & 0.50 & 0.47 & 0.43 & 1.80 & 1.71 & 1.54 & 2.51 & 2.38 & 2.14 \\
\hline $\mathrm{TiO}_{2}$ & 7.38 & 8.58 & 10.67 & 7.27 & 8.49 & 10.69 & 7.25 & 8.44 & 10.64 \\
\hline $\mathrm{U}_{3} \mathrm{O}_{8}$ & 1.65 & 1.56 & 1.41 & 0.94 & 0.89 & 0.80 & 1.35 & 1.28 & 1.16 \\
\hline $\mathrm{ZnO}$ & 0.00 & 0.00 & 0.00 & 0.11 & 0.10 & 0.09 & 0.11 & 0.10 & 0.09 \\
\hline $\mathrm{ZrO}_{2}$ & 0.49 & 1.14 & 2.27 & 0.61 & 1.27 & 2.47 & 0.61 & 1.26 & 2.46 \\
\hline
\end{tabular}


Table A-3. Composition Projections for CST Added to Tank 40 with SWPF Streams at 75 SRAT Batches Annually. (continued)

\begin{tabular}{|c|c|c|c|c|c|c|c|c|c|}
\hline "Sludge Batch & \multicolumn{3}{|c|}{ SB11 } & \multicolumn{3}{|c|}{ SB12 } & \multicolumn{3}{|c|}{ SB13 } \\
\hline SRAT Batch & 1 & 35 & 70 & 1 & 36 & 71 & 1 & 33 & 66 \\
\hline $\mathrm{Al}_{2} \mathrm{O}_{3}$ & 14.08 & 13.44 & 12.29 & 19.66 & 18.69 & 17.00 & 20.50 & 19.54 & 17.86 \\
\hline $\mathrm{BaO}$ & 0.20 & 0.19 & 0.17 & 0.20 & 0.19 & 0.17 & 0.20 & 0.19 & 0.17 \\
\hline $\mathrm{CaO}$ & 2.47 & 2.35 & 2.12 & 2.73 & 2.58 & 2.32 & 2.83 & 2.69 & 2.43 \\
\hline $\mathrm{Ce}_{2} \mathrm{O}_{3}$ & 0.62 & 0.59 & 0.53 & 0.42 & 0.39 & 0.35 & 0.31 & 0.29 & 0.27 \\
\hline $\mathrm{Cr}_{2} \mathrm{O}_{3}$ & 0.26 & 0.25 & 0.22 & 0.39 & 0.37 & 0.33 & 0.39 & 0.37 & 0.33 \\
\hline $\mathrm{CuO}$ & 0.11 & 0.10 & 0.09 & 0.11 & 0.10 & 0.09 & 0.11 & 0.10 & 0.09 \\
\hline $\mathrm{Fe}_{2} \mathrm{O}_{3}$ & 35.15 & 33.32 & 30.08 & 28.01 & 26.50 & 23.87 & 25.91 & 24.59 & 22.28 \\
\hline $\mathrm{K}_{2} \mathrm{O}$ & 0.11 & 0.10 & 0.09 & 0.21 & 0.20 & 0.18 & 0.32 & 0.30 & 0.27 \\
\hline $\mathrm{La}_{2} \mathrm{O}_{3}$ & 0.21 & 0.20 & 0.18 & 0.21 & 0.20 & 0.18 & 0.10 & 0.10 & 0.09 \\
\hline $\mathrm{MgO}$ & 0.44 & 0.42 & 0.38 & 0.44 & 0.42 & 0.38 & 0.29 & 0.28 & 0.25 \\
\hline $\mathrm{MnO}$ & 3.08 & 2.92 & 2.64 & 2.98 & 2.82 & 2.54 & 3.41 & 3.23 & 2.93 \\
\hline $\mathrm{Na}_{2} \mathrm{O}$ & 27.58 & 27.26 & 26.69 & 27.45 & 27.12 & 26.56 & 27.10 & 26.81 & 26.30 \\
\hline $\mathrm{Nb}_{2} \mathrm{O}_{5}$ & 0.02 & 0.96 & 2.61 & 0.02 & 0.99 & 2.67 & 0.02 & 0.94 & 2.53 \\
\hline $\mathrm{NiO}$ & 0.45 & 0.43 & 0.39 & 0.34 & 0.32 & 0.29 & 0.45 & 0.42 & 0.39 \\
\hline $\mathrm{PbO}$ & 0.29 & 0.27 & 0.24 & 0.19 & 0.18 & 0.16 & 0.19 & 0.18 & 0.16 \\
\hline $\mathrm{SiO}_{2}$ & 5.31 & 5.83 & 6.74 & 6.85 & 7.30 & 8.08 & 6.79 & 7.22 & 7.96 \\
\hline $\mathrm{SO}_{4}^{2-}$ & 0.00 & 0.00 & 0.00 & 0.00 & 0.00 & 0.00 & 0.00 & 0.00 & 0.00 \\
\hline $\mathrm{ThO}_{2}$ & 0.70 & 0.67 & 0.60 & 0.00 & 0.00 & 0.00 & 0.00 & 0.00 & 0.00 \\
\hline $\mathrm{TiO}_{2}$ & 7.57 & 8.77 & 10.91 & 7.60 & 8.86 & 11.03 & 7.55 & 8.74 & 10.80 \\
\hline $\mathrm{U}_{3} \mathrm{O}_{8}$ & 0.63 & 0.59 & 0.54 & 1.47 & 1.39 & 1.25 & 2.70 & 2.56 & 2.32 \\
\hline $\mathrm{ZnO}$ & 0.22 & 0.21 & 0.19 & 0.11 & 0.10 & 0.09 & 0.22 & 0.21 & 0.19 \\
\hline $\mathrm{ZrO}_{2}$ & 0.49 & 1.15 & 2.32 & 0.62 & 1.29 & 2.46 & $\begin{array}{l}0.61 \\
\end{array}$ & 1.25 & 2.36 \\
\hline
\end{tabular}


Table A-3. Composition Projections for CST Added to Tank 40 with SWPF Streams at 75 SRAT Batches Annually. (continued)

\begin{tabular}{|c|c|c|c|c|c|c|c|c|c|}
\hline "Sludge Batch & \multicolumn{3}{|c|}{ SB14 } & \multicolumn{3}{|c|}{ SB15 } & \multicolumn{3}{|c|}{ SB16 } \\
\hline SRAT Batch & 1 & 37 & 74 & 1 & 46 & 91 & 1 & 19 & 38 \\
\hline $\mathrm{Al}_{2} \mathrm{O}_{3}$ & 14.39 & 13.72 & 12.51 & 12.70 & 12.10 & 10.96 & 13.34 & 12.86 & 12.14 \\
\hline $\mathrm{BaO}$ & 0.20 & 0.18 & 0.17 & 0.20 & 0.18 & 0.17 & 0.19 & 0.18 & 0.17 \\
\hline $\mathrm{CaO}$ & 2.32 & 2.20 & 1.98 & 2.08 & 1.97 & 1.76 & 2.36 & 2.26 & 2.11 \\
\hline $\mathrm{Ce}_{2} \mathrm{O}_{3}$ & 0.20 & 0.19 & 0.17 & 0.20 & 0.19 & 0.17 & 0.49 & 0.47 & 0.44 \\
\hline $\mathrm{Cr}_{2} \mathrm{O}_{3}$ & 0.38 & 0.36 & 0.33 & 0.26 & 0.24 & 0.22 & 0.25 & 0.24 & 0.22 \\
\hline $\mathrm{CuO}$ & 0.11 & 0.10 & 0.09 & 0.11 & 0.10 & 0.09 & 0.11 & 0.10 & 0.09 \\
\hline $\mathrm{Fe}_{2} \mathrm{O}_{3}$ & 24.49 & 23.21 & 20.88 & 23.63 & 22.36 & 19.97 & 30.51 & 29.23 & 27.31 \\
\hline $\mathrm{K}_{2} \mathrm{O}$ & 0.21 & 0.20 & 0.18 & 0.21 & 0.20 & 0.18 & 0.20 & 0.19 & 0.18 \\
\hline $\mathrm{La}_{2} \mathrm{O}_{3}$ & 0.10 & 0.10 & 0.09 & 0.10 & 0.10 & 0.09 & 0.20 & 0.19 & 0.18 \\
\hline $\mathrm{MgO}$ & 0.29 & 0.27 & 0.25 & 0.29 & 0.27 & 0.25 & 0.28 & 0.27 & 0.25 \\
\hline $\mathrm{MnO}$ & 1.92 & 1.82 & 1.64 & 2.48 & 2.35 & 2.10 & 1.42 & 1.36 & 1.27 \\
\hline $\mathrm{Na}_{2} \mathrm{O}$ & 26.36 & 26.10 & 25.62 & 28.25 & 27.87 & 27.15 & 24.83 & 24.70 & 24.50 \\
\hline $\mathrm{Nb}_{2} \mathrm{O}_{5}$ & 0.02 & 0.96 & 2.66 & 0.02 & 1.00 & 2.83 & 0.04 & 0.77 & 1.88 \\
\hline $\mathrm{NiO}$ & 1.67 & 1.58 & 1.42 & 1.56 & 1.47 & 1.32 & 1.29 & 1.23 & 1.15 \\
\hline $\mathrm{PbO}$ & 0.19 & 0.18 & 0.16 & 0.19 & 0.18 & 0.16 & 0.36 & 0.35 & 0.33 \\
\hline $\mathrm{SiO}_{2}$ & 5.06 & 5.59 & 6.55 & 3.94 & 4.56 & 5.72 & 1.65 & 2.21 & 3.04 \\
\hline $\mathrm{SO}_{4}^{2-}$ & 0.00 & 0.00 & 0.00 & 0.00 & 0.00 & 0.00 & 0.00 & 0.00 & 0.00 \\
\hline $\mathrm{ThO}_{2}$ & 0.00 & 0.00 & 0.00 & 0.00 & 0.00 & 0.00 & 0.00 & 0.00 & 0.00 \\
\hline $\mathrm{TiO}_{2}$ & 7.35 & 8.57 & 10.79 & 7.17 & 8.43 & 10.79 & 8.36 & 9.30 & 10.72 \\
\hline $\mathrm{U}_{3} \mathrm{O}_{8}$ & 14.04 & 13.31 & 11.97 & 16.01 & 15.15 & 13.54 & 13.55 & 12.99 & 12.13 \\
\hline $\mathrm{ZnO}$ & 0.22 & 0.21 & 0.19 & 0.11 & 0.10 & 0.09 & 0.10 & 0.10 & 0.09 \\
\hline $\mathrm{ZrO}_{2}$ & 0.49 & 1.15 & 2.35 & 0.49 & 1.18 & 2.47 & $\begin{array}{l}0.48 \\
\end{array}$ & 1.00 & 1.78 \\
\hline
\end{tabular}


Table A-3. Composition Projections for CST Added to Tank 40 with SWPF Streams at 75 SRAT Batches Annually. (continued)

\begin{tabular}{||c|c|c|c||}
\hline Sludge Batch & \multicolumn{3}{|c|}{ SB17 } \\
\hline SRAT Batch & 1 & 18 & 35 \\
\hline $\mathrm{Al}_{2} \mathrm{O}_{3}$ & 13.65 & 13.18 & 12.51 \\
\hline $\mathrm{BaO}$ & 0.19 & 0.18 & 0.17 \\
\hline $\mathrm{CaO}$ & 2.39 & 2.30 & 2.16 \\
\hline $\mathrm{Ce}_{2} \mathrm{O}_{3}$ & 0.60 & 0.58 & 0.54 \\
\hline $\mathrm{Cr}_{2} \mathrm{O}_{3}$ & 0.25 & 0.24 & 0.23 \\
\hline $\mathrm{CuO}$ & 0.11 & 0.10 & 0.10 \\
\hline $\mathrm{Fe}_{2} \mathrm{O}_{3}$ & 33.52 & 32.19 & 30.27 \\
\hline $\mathrm{K}_{2} \mathrm{O}$ & 0.10 & 0.10 & 0.09 \\
\hline $\mathrm{La}_{2} \mathrm{O}_{3}$ & 0.20 & 0.19 & 0.18 \\
\hline $\mathrm{MgO}_{\mathrm{MnO}}$ & 0.28 & 0.27 & 0.26 \\
\hline $\mathrm{Na}_{2} \mathrm{O}$ & 0.99 & 0.95 & 0.90 \\
\hline $\mathrm{Nb}_{2} \mathrm{O}_{5}$ & 0.04 & 23.54 & 23.42 \\
\hline $\mathrm{NiO}^{2}$ & 1.20 & 0.74 & 1.75 \\
\hline $\mathrm{PbO}_{\mathrm{SiO}}$ & 0.37 & 0.35 & 1.08 \\
\hline $\mathrm{SO}_{2}{ }^{2-}$ & 0.95 & 1.50 & 0.33 \\
\hline $\mathrm{ThO}_{2}$ & 0.00 & 0.00 & 2.31 \\
\hline $\mathrm{TiO}_{2}$ & 7.80 & 0.00 & 0.00 \\
\hline $\mathrm{U}_{3} \mathrm{O}_{8}$ & 13.14 & 12.62 & 10.04 \\
\hline $\mathrm{ZnO}_{\mathrm{ZnO}}$ & 0.11 & 0.10 & 0.10 \\
\hline $\mathrm{ZrO}_{2}$ & 0.49 & 0.98 & 1.70 \\
\hline
\end{tabular}


Table A-4. Composition Projections for CST Added to Tank 51 with SWPF Streams at 75 SRAT Batches Annually.

\begin{tabular}{|c|c|c|c|c|c|c|c|c|c|c|}
\hline $\begin{array}{l}\text { Sludge } \\
\text { Batch }\end{array}$ & SB8 & SB9 & SB10 & SB11 & SB12 & SB13 & SB14 & SB15 & SB16 & SB17 \\
\hline $\mathrm{Al}_{2} \mathrm{O}_{3}$ & 15.13 & 13.64 & 11.57 & 12.96 & 18.36 & 19.10 & 13.33 & 11.93 & 11.45 & 11.77 \\
\hline $\mathrm{BaO}$ & 0.19 & 0.19 & 0.19 & 0.19 & 0.19 & 0.19 & 0.19 & 0.19 & 0.18 & 0.18 \\
\hline $\mathrm{CaO}$ & 2.60 & 2.64 & 2.64 & 2.40 & 2.65 & 2.74 & 2.26 & 2.04 & 2.23 & 2.24 \\
\hline $\mathrm{Ce}_{2} \mathrm{O}_{3}$ & 0.79 & 0.80 & 0.70 & 0.60 & 0.40 & 0.30 & 0.20 & 0.20 & 0.47 & 0.56 \\
\hline $\mathrm{Cr}_{2} \mathrm{O}_{3}$ & 0.25 & 0.25 & 0.25 & 0.25 & 0.38 & 0.37 & 0.37 & 0.25 & 0.23 & 0.23 \\
\hline $\mathrm{CuO}$ & 0.11 & 0.11 & 0.11 & 0.11 & 0.11 & 0.11 & 0.11 & 0.11 & 0.10 & 0.10 \\
\hline $\mathrm{Fe}_{2} \mathrm{O}_{3}$ & 33.54 & 32.20 & 31.74 & 34.07 & 27.18 & 25.07 & 23.80 & 23.13 & 28.89 & 31.40 \\
\hline $\mathrm{K}_{2} \mathrm{O}$ & 0.10 & 0.10 & 0.10 & 0.10 & 0.21 & 0.31 & 0.20 & 0.21 & 0.19 & 0.10 \\
\hline $\mathrm{La}_{2} \mathrm{O}_{3}$ & 0.30 & 0.20 & 0.20 & 0.20 & 0.20 & 0.10 & 0.10 & 0.10 & 0.19 & 0.19 \\
\hline $\mathrm{MgO}$ & 0.42 & 0.43 & 0.43 & 0.43 & 0.43 & 0.28 & 0.28 & 0.28 & 0.26 & 0.27 \\
\hline $\mathrm{MnO}$ & 5.34 & 4.76 & 4.98 & 2.99 & 2.89 & 3.30 & 1.86 & 2.43 & 1.34 & 0.93 \\
\hline $\mathrm{Na}_{2} \mathrm{O}$ & 25.44 & 27.47 & 27.89 & 27.23 & 27.10 & 26.90 & 25.96 & 27.40 & 26.01 & 25.04 \\
\hline $\mathrm{Nb}_{2} \mathrm{O}_{5}$ & 1.30 & 1.39 & 1.41 & 1.35 & 1.35 & 1.30 & 1.34 & 1.45 & 0.96 & 0.94 \\
\hline $\mathrm{NiO}$ & 0.97 & 0.54 & 0.87 & 0.44 & 0.33 & 0.43 & 1.62 & 1.53 & 1.22 & 1.12 \\
\hline $\mathrm{PbO}$ & 0.45 & 0.37 & 0.37 & 0.28 & 0.19 & 0.18 & 0.18 & 0.18 & 0.34 & 0.35 \\
\hline $\mathrm{SiO}_{2}$ & 2.55 & 3.92 & 4.49 & 6.27 & 7.76 & 7.65 & 6.04 & 5.07 & 2.35 & 1.65 \\
\hline $\mathrm{SO}_{4}{ }^{2-}$ & 0.00 & 0.00 & 0.00 & 0.00 & 0.00 & 0.00 & 0.00 & 0.00 & 0.00 & 0.00 \\
\hline $\mathrm{ThO}_{2}$ & 0.48 & 1.75 & 2.44 & 0.68 & 0.00 & 0.00 & 0.00 & 0.00 & 0.00 & 0.00 \\
\hline $\mathrm{TiO}_{2}$ & 7.05 & 6.63 & 6.58 & 7.18 & 7.18 & 7.32 & 6.86 & 6.20 & 9.51 & 9.39 \\
\hline $\mathrm{U}_{3} \mathrm{O}_{8}$ & 1.60 & 0.91 & 1.32 & 0.61 & 1.42 & 2.61 & 13.65 & 15.68 & 12.83 & 12.31 \\
\hline $\mathrm{ZnO}$ & 0.00 & 0.11 & 0.11 & 0.21 & 0.11 & 0.21 & 0.21 & 0.11 & 0.10 & 0.10 \\
\hline $\mathrm{ZrO}_{2}$ & 1.41 & 1.59 & 1.61 & 1.45 & 1.57 & 1.53 & 1.44 & 1.52 & 1.13 & 1.12 \\
\hline
\end{tabular}


Table A-5. Composition Projections for CST Added to Tank 40 without SWPF Streams at 75 SRAT Batches Annually.

\begin{tabular}{|c|c|c|c|c|c|c|c|c|c|}
\hline "Sludge Batch & \multicolumn{3}{|c|}{ SB8 } & \multicolumn{3}{|c|}{ SB9 } & \multicolumn{3}{|c|}{ SB10 } \\
\hline SRAT Batch & 1 & 35 & 69 & 1 & 40 & 79 & 1 & 40 & 80 \\
\hline $\mathrm{Al}_{2} \mathrm{O}_{3}$ & 16.50 & 15.61 & 14.09 & 14.50 & 13.71 & 12.29 & 12.00 & 11.36 & 10.18 \\
\hline $\mathrm{BaO}$ & 0.23 & 0.21 & 0.19 & 0.23 & 0.22 & 0.19 & 0.23 & 0.22 & 0.19 \\
\hline $\mathrm{CaO}$ & 3.13 & 2.96 & 2.67 & 3.15 & 2.98 & 2.67 & 3.15 & 2.98 & 2.67 \\
\hline $\mathrm{Ce}_{2} \mathrm{O}_{3}$ & 0.95 & 0.90 & 0.81 & 0.96 & 0.91 & 0.81 & 0.84 & 0.79 & 0.71 \\
\hline $\mathrm{Cr}_{2} \mathrm{O}_{3}$ & 0.30 & 0.28 & 0.25 & 0.30 & 0.28 & 0.25 & 0.30 & 0.28 & 0.25 \\
\hline $\mathrm{CuO}$ & 0.13 & 0.12 & 0.11 & 0.13 & 0.12 & 0.11 & 0.13 & 0.12 & 0.11 \\
\hline $\mathrm{Fe}_{2} \mathrm{O}_{3}$ & 40.37 & 38.20 & 34.49 & 38.50 & 36.39 & 32.61 & 37.94 & 35.91 & 32.18 \\
\hline $\mathrm{K}_{2} \mathrm{O}$ & 0.12 & 0.12 & 0.10 & 0.12 & 0.12 & 0.10 & 0.12 & 0.12 & 0.10 \\
\hline $\mathrm{La}_{2} \mathrm{O}_{3}$ & 0.36 & 0.34 & 0.31 & 0.24 & 0.23 & 0.20 & 0.24 & 0.23 & 0.20 \\
\hline $\mathrm{MgO}$ & 0.51 & 0.48 & 0.43 & 0.51 & 0.48 & 0.43 & 0.51 & 0.48 & 0.43 \\
\hline $\mathrm{MnO}$ & 6.43 & 6.08 & 5.49 & 5.69 & 5.37 & 4.82 & 5.95 & 5.63 & 5.05 \\
\hline $\mathrm{Na}_{2} \mathrm{O}$ & 23.36 & 23.13 & 22.75 & 26.17 & 25.78 & 25.09 & 26.73 & 26.33 & 25.58 \\
\hline $\mathrm{Nb}_{2} \mathrm{O}_{5}$ & 0.03 & 1.10 & 2.95 & 0.02 & 1.12 & 3.10 & 0.02 & 1.10 & 3.07 \\
\hline $\mathrm{NiO}$ & 1.16 & 1.10 & 0.99 & 0.65 & 0.62 & 0.55 & 1.04 & 0.99 & 0.88 \\
\hline $\mathrm{PbO}$ & 0.55 & 0.52 & 0.47 & 0.44 & 0.42 & 0.37 & 0.44 & 0.42 & 0.37 \\
\hline $\mathrm{SiO}_{2}$ & 1.76 & 2.58 & 3.98 & 3.30 & 4.06 & 5.40 & 3.96 & 4.66 & 5.95 \\
\hline $\mathrm{SO}_{4}{ }^{2-}$ & 0.00 & 0.00 & 0.00 & 0.00 & 0.00 & 0.00 & 0.00 & 0.00 & 0.00 \\
\hline $\mathrm{ThO}_{2}$ & 0.58 & 0.55 & 0.49 & 2.10 & 1.98 & 1.78 & 2.91 & 2.76 & 2.47 \\
\hline $\mathrm{TiO}_{2}$ & 1.08 & 2.57 & 5.14 & 1.06 & 2.59 & 5.33 & 1.06 & 2.55 & 5.30 \\
\hline $\mathrm{U}_{3} \mathrm{O}_{8}$ & 1.92 & 1.82 & 1.64 & 1.09 & 1.03 & 0.92 & 1.57 & 1.49 & 1.33 \\
\hline $\mathrm{ZnO}$ & 0.00 & 0.00 & 0.00 & 0.13 & 0.12 & 0.11 & 0.13 & 0.12 & 0.11 \\
\hline $\mathrm{ZrO}_{2}$ & 0.57 & 1.33 & 2.63 & 0.71 & 1.48 & 2.85 & 0.71 & 1.46 & 2.84 \\
\hline
\end{tabular}


Table A-5. Composition Projections for CST Added to Tank 40 without SWPF Streams at 75 SRAT Batches Annually. (continued)

\begin{tabular}{|c|c|c|c|c|c|c|c|c|c|}
\hline "Sludge Batch & \multicolumn{3}{|c|}{ SB11 } & \multicolumn{3}{|c|}{ SB12 } & \multicolumn{3}{|c|}{ SB13 } \\
\hline SRAT Batch & 1 & 35 & 70 & 1 & 36 & 71 & 1 & 33 & 66 \\
\hline $\mathrm{Al}_{2} \mathrm{O}_{3}$ & 13.90 & 13.14 & 11.81 & 20.44 & 19.29 & 17.30 & 21.41 & 20.27 & 18.30 \\
\hline $\mathrm{BaO}$ & 0.23 & 0.22 & 0.20 & 0.23 & 0.22 & 0.20 & 0.23 & 0.22 & 0.20 \\
\hline $\mathrm{CaO}$ & 2.90 & 2.74 & 2.46 & 3.20 & 3.02 & 2.71 & 3.31 & 3.14 & 2.83 \\
\hline $\mathrm{Ce}_{2} \mathrm{O}_{3}$ & 0.73 & 0.69 & 0.62 & 0.49 & 0.46 & 0.41 & 0.36 & 0.34 & 0.31 \\
\hline $\mathrm{Cr}_{2} \mathrm{O}_{3}$ & 0.30 & 0.29 & 0.26 & 0.46 & 0.43 & 0.39 & 0.45 & 0.43 & 0.39 \\
\hline $\mathrm{CuO}$ & 0.13 & 0.12 & 0.11 & 0.13 & 0.12 & 0.11 & 0.13 & 0.12 & 0.11 \\
\hline $\mathrm{Fe}_{2} \mathrm{O}_{3}$ & 41.18 & 38.95 & 35.01 & 32.88 & 31.02 & 27.83 & 30.34 & 28.73 & 25.94 \\
\hline $\mathrm{K}_{2} \mathrm{O}$ & 0.12 & 0.12 & 0.11 & 0.25 & 0.24 & 0.21 & 0.37 & 0.35 & 0.32 \\
\hline $\mathrm{La}_{2} \mathrm{O}_{3}$ & 0.24 & 0.23 & 0.21 & 0.24 & 0.23 & 0.21 & 0.12 & 0.11 & 0.10 \\
\hline $\mathrm{MgO}$ & 0.52 & 0.49 & 0.44 & 0.52 & 0.49 & 0.44 & 0.34 & 0.32 & 0.29 \\
\hline $\mathrm{MnO}$ & 3.61 & 3.42 & 3.07 & 3.49 & 3.30 & 2.96 & 3.99 & 3.78 & 3.41 \\
\hline $\mathrm{Na}_{2} \mathrm{O}$ & 25.51 & 25.17 & 24.56 & 25.33 & 24.98 & 24.38 & 24.95 & 24.64 & 24.11 \\
\hline $\mathrm{Nb}_{2} \mathrm{O}_{5}$ & 0.03 & 1.12 & 3.04 & 0.03 & 1.16 & 3.11 & 0.03 & 1.09 & 2.94 \\
\hline $\mathrm{NiO}$ & 0.53 & 0.50 & 0.45 & 0.40 & 0.37 & 0.34 & 0.52 & 0.50 & 0.45 \\
\hline $\mathrm{PbO}$ & 0.33 & 0.32 & 0.28 & 0.22 & 0.21 & 0.19 & 0.22 & 0.21 & 0.19 \\
\hline $\mathrm{SiO}_{2}$ & 6.23 & 6.81 & 7.85 & 8.03 & 8.54 & 9.42 & 7.96 & 8.44 & 9.27 \\
\hline $\mathrm{SO}_{4}{ }^{2-}$ & 0.00 & 0.00 & 0.00 & 0.00 & 0.00 & 0.00 & 0.00 & 0.00 & 0.00 \\
\hline $\mathrm{ThO}_{2}$ & 0.83 & 0.78 & 0.70 & 0.00 & 0.00 & 0.00 & 0.00 & 0.00 & 0.00 \\
\hline $\mathrm{TiO}_{2}$ & 1.11 & 2.62 & 5.29 & 1.08 & 2.65 & 5.37 & 1.12 & 2.60 & 5.16 \\
\hline $\mathrm{U}_{3} \mathrm{O}_{8}$ & 0.73 & 0.69 & 0.62 & 1.72 & 1.62 & 1.46 & 3.16 & 3.00 & 2.71 \\
\hline $\mathrm{ZnO}$ & 0.26 & 0.24 & 0.22 & 0.13 & 0.12 & 0.11 & 0.26 & 0.24 & 0.22 \\
\hline $\mathrm{ZrO}_{2}$ & 0.58 & 1.35 & 2.70 & 0.72 & 1.51 & 2.87 & 0.72 & $\begin{array}{l}1.46 \\
\end{array}$ & 2.75 \\
\hline
\end{tabular}


Table A-5. Composition Projections for CST Added to Tank 40 without SWPF Streams at 75 SRAT Batches Annually. (continued)

\begin{tabular}{|c|c|c|c|c|c|c|c|c|c|}
\hline "Sludge Batch & \multicolumn{3}{|c|}{ SB14 } & \multicolumn{3}{|c|}{ SB15 } & \multicolumn{3}{|c|}{ SB16 } \\
\hline SRAT Batch & 1 & 37 & 74 & 1 & 46 & 91 & 1 & 19 & 38 \\
\hline $\mathrm{Al}_{2} \mathrm{O}_{3}$ & 14.25 & 13.48 & 12.09 & 12.30 & 11.60 & 10.31 & 13.00 & 12.44 & 11.59 \\
\hline $\mathrm{BaO}$ & 0.23 & 0.22 & 0.19 & 0.23 & 0.21 & 0.19 & 0.22 & 0.21 & 0.20 \\
\hline $\mathrm{CaO}$ & 2.71 & 2.56 & 2.30 & 2.42 & 2.28 & 2.03 & 2.79 & 2.67 & 2.49 \\
\hline $\mathrm{Ce}_{2} \mathrm{O}_{3}$ & 0.24 & 0.23 & 0.20 & 0.24 & 0.22 & 0.20 & 0.58 & 0.56 & 0.52 \\
\hline $\mathrm{Cr}_{2} \mathrm{O}_{3}$ & 0.45 & 0.42 & 0.38 & 0.30 & 0.28 & 0.25 & 0.29 & 0.28 & 0.26 \\
\hline $\mathrm{CuO}$ & 0.13 & 0.12 & 0.11 & 0.13 & 0.12 & 0.11 & 0.12 & 0.12 & 0.11 \\
\hline $\mathrm{Fe}_{2} \mathrm{O}_{3}$ & 28.58 & 27.03 & 24.23 & 27.49 & 25.93 & 23.05 & 36.08 & 34.52 & 32.18 \\
\hline $\mathrm{K}_{2} \mathrm{O}$ & 0.25 & 0.23 & 0.21 & 0.25 & 0.23 & 0.21 & 0.24 & 0.23 & 0.21 \\
\hline $\mathrm{La}_{2} \mathrm{O}_{3}$ & 0.12 & 0.11 & 0.10 & 0.12 & 0.11 & 0.10 & 0.23 & 0.22 & 0.21 \\
\hline $\mathrm{MgO}$ & 0.34 & 0.32 & 0.29 & 0.34 & 0.32 & 0.28 & 0.33 & 0.32 & 0.30 \\
\hline $\mathrm{MnO}$ & 2.24 & 2.12 & 1.90 & 2.89 & 2.73 & 2.42 & 1.67 & 1.60 & 1.49 \\
\hline $\mathrm{Na}_{2} \mathrm{O}$ & 24.13 & 23.86 & 23.38 & 26.39 & 25.98 & 25.22 & 22.12 & 21.99 & 21.80 \\
\hline $\mathrm{Nb}_{2} \mathrm{O}_{5}$ & 0.03 & 1.12 & 3.08 & 0.02 & 1.16 & 3.27 & 0.04 & 0.91 & 2.21 \\
\hline $\mathrm{NiO}$ & 1.95 & 1.84 & 1.65 & 1.81 & 1.71 & 1.52 & 1.52 & 1.46 & 1.36 \\
\hline $\mathrm{PbO}$ & 0.22 & 0.21 & 0.19 & 0.22 & 0.21 & 0.18 & 0.43 & 0.41 & 0.38 \\
\hline $\mathrm{SiO}_{2}$ & 5.91 & 6.51 & 7.60 & 4.59 & 5.29 & 6.60 & 1.96 & 2.61 & 3.59 \\
\hline $\mathrm{SO}_{4}{ }^{2-}$ & 0.00 & 0.00 & 0.00 & 0.00 & 0.00 & 0.00 & 0.00 & 0.00 & 0.00 \\
\hline $\mathrm{ThO}_{2}$ & 0.00 & 0.00 & 0.00 & 0.00 & 0.00 & 0.00 & 0.00 & 0.00 & 0.00 \\
\hline $\mathrm{TiO}_{2}$ & 1.03 & 2.54 & 5.28 & 0.97 & 2.55 & 5.49 & 1.63 & 2.82 & 4.59 \\
\hline $\mathrm{U}_{3} \mathrm{O}_{8}$ & 16.39 & 15.50 & 13.89 & 18.63 & 17.58 & 15.62 & 16.03 & 15.33 & 14.29 \\
\hline $\mathrm{ZnO}$ & 0.25 & 0.24 & 0.22 & 0.13 & 0.12 & 0.11 & 0.12 & 0.12 & 0.11 \\
\hline $\mathrm{ZrO}_{2}$ & 0.57 & 1.34 & 2.72 & 0.56 & 1.36 & 2.85 & $\begin{array}{l}0.57 \\
\end{array}$ & 1.18 & 2.10 \\
\hline
\end{tabular}


Table A-5. Composition Projections for CST Added to Tank 40 without SWPF Streams at 75 SRAT Batches Annually. (continued)

\begin{tabular}{|c|c|c|c|}
\hline Sludge Batch & \multicolumn{3}{|c|}{ SB17 } \\
\hline SRAT Batch & 1 & 18 & 35 \\
\hline $\mathrm{Al}_{2} \mathrm{O}_{3}$ & 13.40 & 12.85 & 12.06 \\
\hline $\mathrm{BaO}$ & 0.22 & 0.21 & 0.20 \\
\hline $\mathrm{CaO}$ & 2.80 & 2.68 & 2.52 \\
\hline $\mathrm{Ce}_{2} \mathrm{O}_{3}$ & 0.70 & 0.67 & 0.63 \\
\hline $\mathrm{Cr}_{2} \mathrm{O}_{3}$ & 0.29 & 0.28 & 0.26 \\
\hline $\mathrm{CuO}$ & 0.13 & 0.12 & 0.11 \\
\hline $\mathrm{Fe}_{2} \mathrm{O}_{3}$ & 39.14 & 37.54 & 35.24 \\
\hline $\mathrm{K}_{2} \mathrm{O}$ & 0.12 & 0.12 & 0.11 \\
\hline $\mathrm{La}_{2} \mathrm{O}_{3}$ & 0.23 & 0.22 & 0.21 \\
\hline $\mathrm{MgO}$ & 0.33 & 0.32 & 0.30 \\
\hline $\mathrm{MnO}$ & 1.16 & 1.11 & 1.05 \\
\hline $\mathrm{Na}_{2} \mathrm{O}$ & 20.93 & 20.86 & 20.75 \\
\hline $\mathrm{Nb}_{2} \mathrm{O}_{5}$ & 0.04 & 0.86 & 2.04 \\
\hline $\mathrm{NiO}$ & 1.40 & 1.34 & 1.26 \\
\hline $\mathrm{PbO}$ & 0.43 & 0.41 & 0.39 \\
\hline $\mathrm{SiO}_{2}$ & 1.10 & 1.75 & 2.69 \\
\hline $\mathrm{SO}_{4}^{2-}$ & 0.00 & 0.00 & 0.00 \\
\hline $\mathrm{ThO}_{2}$ & 0.00 & 0.00 & 0.00 \\
\hline $\mathrm{TiO}_{2}$ & 1.54 & 2.66 & 4.27 \\
\hline $\mathrm{U}_{3} \mathrm{O}_{8}$ & 15.35 & 14.72 & 13.82 \\
\hline $\mathrm{ZnO}$ & 0.12 & 0.12 & 0.11 \\
\hline $\mathrm{ZrO}_{2}$ & 0.57 & 1.15 & 1.98 \\
\hline
\end{tabular}


Table A-6. Composition Projections for CST Added to Tank 51 without SWPF Streams at 75 SRAT Batches Annually.

\begin{tabular}{|c|c|c|c|c|c|c|c|c|c|c|}
\hline $\begin{array}{l}\text { Sludge } \\
\text { Batch }\end{array}$ & SB8 & SB9 & SB10 & SB11 & SB12 & SB13 & SB14 & SB15 & SB16 & SB17 \\
\hline $\mathrm{Al}_{2} \mathrm{O}_{3}$ & 15.39 & 13.47 & 11.13 & 12.93 & 19.02 & 19.96 & 13.27 & 11.39 & 12.35 & 12.74 \\
\hline $\mathrm{BaO}$ & 0.21 & 0.21 & 0.21 & 0.22 & 0.22 & 0.21 & 0.21 & 0.21 & 0.21 & 0.21 \\
\hline $\mathrm{CaO}$ & 2.92 & 2.93 & 2.93 & 2.70 & 2.98 & 3.09 & 2.52 & 2.24 & 2.65 & 2.66 \\
\hline $\mathrm{Ce}_{2} \mathrm{O}_{3}$ & 0.89 & 0.89 & 0.78 & 0.68 & 0.45 & 0.34 & 0.22 & 0.22 & 0.55 & 0.67 \\
\hline $\mathrm{Cr}_{2} \mathrm{O}_{3}$ & 0.28 & 0.28 & 0.28 & 0.28 & 0.42 & 0.42 & 0.42 & 0.28 & 0.28 & 0.28 \\
\hline $\mathrm{CuO}$ & 0.12 & 0.12 & 0.12 & 0.12 & 0.12 & 0.12 & 0.12 & 0.12 & 0.12 & 0.12 \\
\hline $\mathrm{Fe}_{2} \mathrm{O}_{3}$ & 37.66 & 35.77 & 35.20 & 38.32 & 30.59 & 28.30 & 26.61 & 25.46 & 34.27 & 37.21 \\
\hline $\mathrm{K}_{2} \mathrm{O}$ & 0.11 & 0.11 & 0.11 & 0.12 & 0.23 & 0.35 & 0.23 & 0.23 & 0.23 & 0.11 \\
\hline $\mathrm{La}_{2} \mathrm{O}_{3}$ & 0.33 & 0.22 & 0.22 & 0.23 & 0.23 & 0.11 & 0.11 & 0.11 & 0.22 & 0.22 \\
\hline $\mathrm{MgO}$ & 0.47 & 0.47 & 0.47 & 0.48 & 0.48 & 0.32 & 0.31 & 0.31 & 0.31 & 0.32 \\
\hline $\mathrm{MnO}$ & 6.00 & 5.28 & 5.52 & 3.36 & 3.25 & 3.72 & 2.08 & 2.68 & 1.59 & 1.10 \\
\hline $\mathrm{Na}_{2} \mathrm{O}$ & 23.16 & 25.75 & 26.27 & 25.15 & 24.99 & 24.65 & 23.87 & 25.94 & 22.06 & 20.92 \\
\hline $\mathrm{Nb}_{2} \mathrm{O}_{5}$ & 1.46 & 1.54 & 1.56 & 1.52 & 1.52 & 1.47 & 1.50 & 1.59 & 1.14 & 1.11 \\
\hline $\mathrm{NiO}$ & 1.09 & 0.61 & 0.97 & 0.49 & 0.37 & 0.49 & 1.81 & 1.68 & 1.45 & 1.33 \\
\hline $\mathrm{PbO}$ & 0.51 & 0.41 & 0.41 & 0.31 & 0.21 & 0.21 & 0.20 & 0.20 & 0.41 & 0.41 \\
\hline $\mathrm{SiO}_{2}$ & 2.86 & 4.36 & 4.98 & 7.06 & 8.74 & 8.64 & 6.75 & 5.58 & 2.79 & 1.96 \\
\hline $\mathrm{SO}_{4}{ }^{2-}$ & 0.00 & 0.00 & 0.00 & 0.00 & 0.00 & 0.00 & 0.00 & 0.00 & 0.00 & 0.00 \\
\hline $\mathrm{ThO}_{2}$ & 0.54 & 1.95 & 2.70 & 0.77 & 0.00 & 0.00 & 0.00 & 0.00 & 0.00 & 0.00 \\
\hline $\mathrm{TiO}_{2}$ & 2.64 & 2.72 & 2.75 & 2.73 & 2.71 & 2.68 & 2.64 & 2.72 & 2.69 & 2.58 \\
\hline $\mathrm{U}_{3} \mathrm{O}_{8}$ & 1.79 & 1.01 & 1.46 & 0.68 & 1.60 & 2.95 & 15.26 & 17.25 & 15.23 & 14.59 \\
\hline $\mathrm{ZnO}$ & 0.00 & 0.12 & 0.12 & 0.24 & 0.12 & 0.24 & 0.24 & 0.12 & 0.12 & 0.12 \\
\hline $\mathrm{ZrO}_{2}$ & 1.58 & 1.77 & 1.79 & 1.63 & 1.76 & 1.72 & 1.61 & 1.68 & 1.34 & 1.33 \\
\hline
\end{tabular}


Table A-7. Sludge-Only Composition Projections for SB8, SB16 and SB17.

\begin{tabular}{|c|c|c|c|}
\hline $\begin{array}{l}\text { Sludge } \\
\text { Batch }\end{array}$ & SB8 & SB16 & SB17 \\
\hline $\mathrm{Al}_{2} \mathrm{O}_{3}$ & 16.73 & 13.28 & 13.67 \\
\hline $\mathrm{BaO}$ & 0.23 & 0.23 & 0.23 \\
\hline $\mathrm{CaO}$ & 3.17 & 2.85 & 2.85 \\
\hline $\mathrm{Ce}_{2} \mathrm{O}_{3}$ & 0.96 & 0.60 & 0.72 \\
\hline $\mathrm{Cr}_{2} \mathrm{O}_{3}$ & 0.30 & 0.30 & 0.30 \\
\hline $\mathrm{CuO}$ & 0.13 & 0.13 & 0.13 \\
\hline $\mathrm{Fe}_{2} \mathrm{O}_{3}$ & 40.93 & 36.85 & 39.92 \\
\hline $\mathrm{K}_{2} \mathrm{O}$ & 0.12 & 0.25 & 0.12 \\
\hline $\mathrm{La}_{2} \mathrm{O}_{3}$ & 0.36 & 0.24 & 0.24 \\
\hline $\mathrm{MgO}$ & 0.51 & 0.34 & 0.34 \\
\hline $\mathrm{MnO}$ & 6.52 & 1.71 & 1.18 \\
\hline $\mathrm{Na}_{2} \mathrm{O}$ & 23.45 & 22.24 & 21.02 \\
\hline $\mathrm{Nb}_{2} \mathrm{O}_{5}$ & 0.00 & 0.00 & 0.00 \\
\hline $\mathrm{NiO}$ & 1.18 & 1.56 & 1.43 \\
\hline $\mathrm{PbO}$ & 0.55 & 0.44 & 0.44 \\
\hline $\mathrm{SiO}_{2}$ & 1.76 & 1.96 & 1.09 \\
\hline $\mathrm{SO}_{4}{ }^{2-}$ & 0.00 & 0.00 & 0.00 \\
\hline $\mathrm{ThO}_{2}$ & 0.59 & 0.00 & 0.00 \\
\hline $\mathrm{TiO}_{2}$ & 0.00 & 0.00 & 0.00 \\
\hline $\mathrm{U}_{3} \mathrm{O}_{8}$ & 1.95 & 16.37 & 15.65 \\
\hline $\mathrm{ZnO}$ & 0.00 & 0.13 & 0.13 \\
\hline $\mathrm{ZrO}_{2}$ & 0.56 & 0.55 & 0.55 \\
\hline
\end{tabular}




\section{Distribution:}

C. J. Bannochie, 773-42A

A. B. Barnes, 999-W

A. L. Billings, 999-W

J. M. Bricker, 704-27S

D. C. Bumgardner, 766-H

A. S. Choi, 773-42A

C. L. Crawford, 773-42A

T. B. Edwards, 999-W

T. L. Fellinger, 704-26S

S. D. Fink, 773-A

K. M. Fox, 999-W

B. J. Giddings, 786-5A

J. M. Gillam, 766-H

B. A. Hamm, 766-H

C. C. Herman, 999-W

D. T. Herman, 735-11A

E. W. Holtzscheiter, 704-15S

T. H. Huff, 766-H

J. F. Iaukea, 704-30S

C. M. Jantzen, 773-A
F. C. Johnson, 999-W

M. T. Keefer, 241-156H

D. C. Koopman, 999-W

P.L. Lee, 773-42A

S. L. Marra, 773-A

D. J. McCabe, 773-42A

R. T. McNew, 704-27S

D. H. Miller, 999-W

J. E. Occhipinti, 704-S

D. K. Peeler, 999-W

F. M. Pennebaker, 773-42A

H. M. Pittman, 704-27S

F. C. Raszewski, 999-W

J. W. Ray, 704-S

M. A. Rios-Armstrong, 766-H

H. B. Shah, 766-H

D. C. Sherburne, 704-S

M. E. Stone, 999-W

W. R. Wilmarth, 773-A 